\title{
Tapping the potential of grafting to improve the performance of vegetable cropping systems in sub-Saharan Africa. A review
}

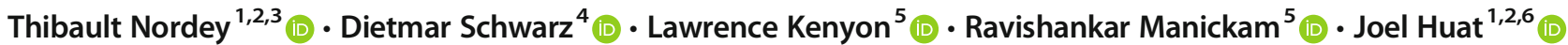

Accepted: 5 June 2020 / Published online: 7 July 2020

(C) INRAE and Springer-Verlag France SAS, part of Springer Nature 2020

\begin{abstract}
Vegetable grafting is developing worldwide to cope with biotic and abiotic stresses. This technique faces strong regional disparities and its potential to improve crop performances is currently underexploited in sub-Saharan Africa. This review explores the potential of grafting to increase and secure vegetable production in challenging production conditions in subSaharan Africa and to identify the obstacles to its adoption. The major conclusions that can be drawn from the review are (1) the capacity of vegetable grafting to overcome several agronomic challenges commonly encountered in sub-Saharan Africa particularly for soilborne diseases; (2) grafting does not systematically lead to higher yields since the performance of grafted plants is closely linked with the combination of scion-rootstock chosen; (3) resistant rootstocks to the local soilborne pathogens could be identified through short-term laboratory and field experiments whereas the improvement of the tolerance to abiotic stresses would require deeper knowledge on underlying mechanisms; (4) the significant increase in the cost of using grafted plants are warranted in systems where there are no other technical alternatives to manage biotic and abiotic stresses, where profitability per plant is high, or where the use of grafted plants makes it possible to reach a profitable niche market such as off-season or organic products; and (5) vegetable grafting should therefore be promoted by providing evidence for its profitability in different production systems (open field and greenhouse cultivation) combined with supply-side interventions to build or strengthen the capacity of nursery operators to provide a continuous supply of good-quality grafted plants.
\end{abstract}

Keywords Cucurbitaceae $\cdot$ Solanaceae $\cdot$ Rootstock $\cdot$ Soilborne pathogen $\cdot$ Africa $\cdot$ Abiotic stresses

\section{Contents}

1. Introduction

2. Is vegetable grafting a suitable technique to overcome agronomic constraints in sub-Saharan Africa?

Thibault Nordey

thibault.nordey@cirad.fr

CIRAD, UPR Hortsys, F-34398 Montpellier, France

2 Hortsys, Univ Montpellier, CIRAD, Montpellier, France

3 World Vegetable Center, Eastern, and Southern Africa, P.O. Box 10, Duluti, Arusha, Tanzania

4 Leibniz Institute of Vegetable and Ornamental Crops (IGZ), Theodor Echtermeyer Weg 1, 14979 Großbeeren, Germany

5 World Vegetable Center, P.O. Box 42, Shanhua, Tainan 74199, Taiwan

6 CIRAD, UPR Hortsys, F-97455 Saint-Pierre, La Réunion, France
2.1 Biotic stresses

2.1.1 Root-knot nematodes

2.1.2 Bacterial wilt

2.1.3 Fusarium wilt

2.1.4 Verticillium wilt

2.1.5. Other wilting diseases and pests

2.2 Abiotic stresses

2.1.1. High temperatures

2.1.2. Drought and flood events

2.1.3. Nutrient deficiency or imbalances in the soil

3. Adaption to economic and cultural contexts

3.1 Grafting is not a silver bullet

3.2 Finding suitable combinations of scions and rootstocks

3.3 Problems involved in obtaining grafted plants

3.4 The profitability of using grafted plants

4. Conclusions

References 


\section{Introduction}

After a prolonged decline, the number of undernourished people increased to 821 million in the last 2 years. Africa is the continent with the highest prevalence of undernourishment which reached $20.4 \%$ in 2017 (FAO et al. 2018). Diversification of diets with fruits and vegetables, excellent sources of micronutrients, is essential for reversing malnutrition. However, year-round access to fruits and vegetables is challenged by the seasonality of production and product perishability exacerbated by the lack of proper storage facilities in sub-Saharan Africa (SSA), responsible for post-harvest losses of up to $55.9 \%$ for fruits and $43.5 \%$ for vegetables (Affognon et al. 2015).

The main vegetables produced in Africa in 2017 are tomatoes (Solanum lycopersicum, 21.5 MT), onions (Allium sativum, $12.2 \mathrm{MT}$ ), cabbage and other Brassicaceae (Brassica oleracea, $3.4 \mathrm{MT}$ ), chilies and sweet peppers (Capsicum annuum, $3.3 \mathrm{MT}$ ), and okra (Abelmoschus esculentus, 3.2 MT) (FAOSTAT 2017). Actual yields of vegetables are far below their potential: in most countries in SSA, the average yield of tomatoes is less than $15 \mathrm{Mg} \mathrm{ha}^{-1}$ (Fig. 2a) whereas models estimate potential yields for open field cultivation - the maximum theoretical yield achieved in a defined environment - at between 50 and $160 \mathrm{Mg} \mathrm{ha}^{-1}$ (Fig. 2c). Several factors hinder vegetable production in SSA including abiotic stresses, i.e., drought, flooding, poor soil fertility, and high temperatures, and biotic stresses related to insect pests, diseases, and weeds.

Additionally, the productivity of horticultural crops is expected to be impacted by climate change with an increase in extreme weather events, i.e., drought, floods, and storm, in the near future, thereby threatening food security (Schlenker and Lobell 2010). Poor farmers in developing countries are expected to be particularly impacted by climate changes because of the low resilience of their cropping systems (Dube et al. 2016). Climate change is also changing the distribution of species worldwide. The tomato leaf miner (Tuta absoluta) is a recent example of an invasive pest, which, after invading the Mediterranean region, currently threatens tomato production in SSA (Mansour et al. 2018).

There is an ongoing debate around the most appropriate agricultural practices to address the double and somehow paradoxical challenge of increasing the food production while reducing the use of synthetic agricultural inputs, i.e., fertilizer and pesticides, which have largely contributed to increasing yields. Practices such as the use of improved varieties, drip irrigation, organic fertilization, reduce tillage, and biological pest control are often mentioned as ways to take up this challenge because of their efficiency and ease of integration in current cropping systems, although it is also claimed that sustainable intensification requires reinventing or profoundly changing existing cropping systems (Wezel et al. 2013;
Doré et al. 2011). It is generally argued that the limited results of the green revolution in SSA are partially due to the limited used of improved varieties, fertilizer, and irrigation. It was estimated that improved varieties contributed around $20 \%$ of the growth rate of yield in all developing countries during the early green revolution, i.e., from 1961 to 1980 , versus only $8 \%$ in SSA, while the introduction of suitable varieties during the late green revolution from 1981 to 2000 was found to be the main driver of yield improvement in SSA during this period (Evenson and Gollin 2003). The supply of improved and adapted varieties is still believed to be a key lever to improve the productivity of vegetable cropping systems (Schreinemachers et al. 2018). Plant breeding is a long process and is hindered by the complexity of combining various traits - high yield, quality, resistance to biotic and tolerance to abiotic stresses - in the same genotype. Grafting, the union of two plant parts, a rootstock (base of the union that provides the root system) and a scion (the upper part that carries the harvestable yield) is seen as a complementary technique to breeding to combine the genetic potential of two plants. This technique has been used in Asia and Europe for thousands of years, as evidenced by the mention of grafting in Chinese, Roman, and Greek writings several century BCE (Mudge et al. 2009). Interest in vegetable grafting has increased with the intensification of cropping systems, notably with the development of greenhouse cultivation in the 1950s and the phasing out of several chemicals used to control soilborne pathogens such as methyl bromide and carbosulfan. Although efforts have been made to identify different alternatives to chemicals, including the use of plant extracts (Deberdt et al. 2012), intercropping (Deberdt et al. 2015), use of compost or by-products of compost (Noble and Coventry 2010), and soil solarization, grafting is considered as one of the most effective ways to grow fruits and vegetables in soil containing soilborne pathogens. The advantages of grafting to improve yields of vegetables by increasing plant tolerance to abiotic stresses and their resistance to biotic stresses were discussed in several reviews (Rouphael et al. 2017a; Keatinge et al. 2014; Louws et al. 2010). Several comprehensive reviews helped understand the impact of grafting on the plant physiology (Goldschmidt 2014; Albacete et al. 2015) and quality of fruits (Kyriacou et al. 2017; Rouphael et al. 2010) and discussed the potential of vegetable grafting to tackle food security issues (Keatinge et al. 2014).

Today, grafting is widely used in commercial orchards of avocado, mango, or citrus in Africa but the potential of this technique for vegetable crops remains largely unknown and untapped (Fig. 1), except in the most northern and southern countries in Africa (Besri 2008). This review explores the potential of grafting to increase and secure vegetable production in challenging environments in SSA and attempts to identify the factors that hinder the practice. First, we review the major biotic and abiotic constraints to vegetable production in 

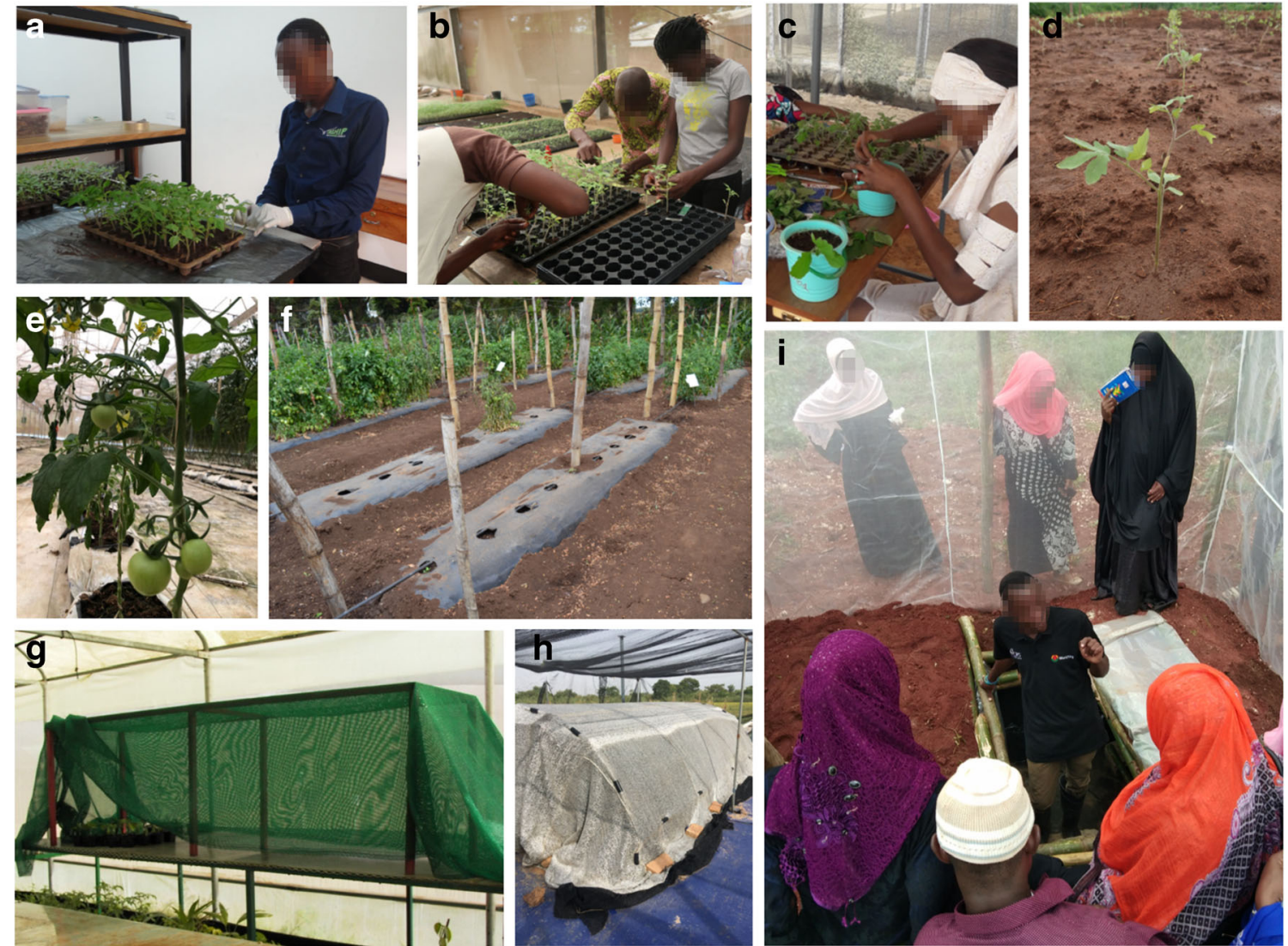
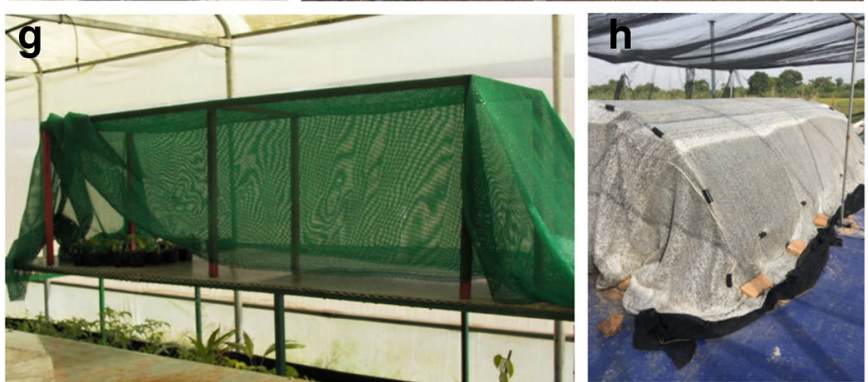

credit: Elias Shem (a, f, i World Vegetable Center), Judith Honfoga (b, d), Wubetu Legesse (c, e, World Vegetable Center), and Joël Huat (g, CIRAD) in Mali (h tunnel under shade nets) and in Tanzania (i underground chamber) and for recovering grafted plants in Mayotte Island (g). Photo

SSA and discuss the advantages of grafting to overcome them. Both production constraints and advantages of grafting valid for SSA are often also valid for regions with similar climatic conditions in the world and are therefore described exemplary. In the second part, we discuss the limitations of grafting and potential bottlenecks to its diffusion in SSA. The results of this review should help identify the work that remains to be done and help choose a suitable approach to promote vegetable grafting in SSA.

\section{Is vegetable grafting a suitable technique to overcome agronomic constraints in sub-Saharan Africa?}

In their review, Lee et al. (2010) listed 16 major advantages of grafted plants including notably improved productivity, an extended harvest period, increased resistance to soilborne pathogens, and higher tolerance to abiotic stresses (sub- and supra-optimal temperatures, drought, and soil salinity). Improved traits of grafted plants are generally attributed to a more vigorous root system that improves plant water and nutrient uptake, a stronger antioxidative defense system, changes in hormonal balances, and improved photosynthetic efficiency (Albacete et al. 2015). The following sections identify in what ways the improved traits of grafted plants would help to address agronomic constraints in SSA.

\subsection{Biotic stresses}

The main families of vegetables cultivated worldwide, called global vegetables, Solanaceae (tomato, eggplant, pepper), Cucurbitaceae (cucumber, pumpkins, and squash), Allium (onion, shallot, and garlic), Fabaceae (common bean, pea), and Brassicaceae (cabbage, cauliflower) are also widely cultivated in SSA. Other vegetables, called traditional vegetables, such as African nightshade (Solanum scabrum), okra (Abelmoschus esculentus), amaranth (Amaranthus spp.), and African eggplant (Solanum aethiopicum and Solanum macrocarpon) are also important for both household income and diets, although statistics on their production are lacking (Schreinemachers et al. 2018). Several soilborne pathogens affect both global and traditional vegetable species. Due to their severity, their wide range of hosts and their distribution in Africa (Fig. 2), Root-knot nematodes (Meloidogyne spp.), Verticillium wilt, Fusarium wilt, and Ralstonia solanacearum 
a

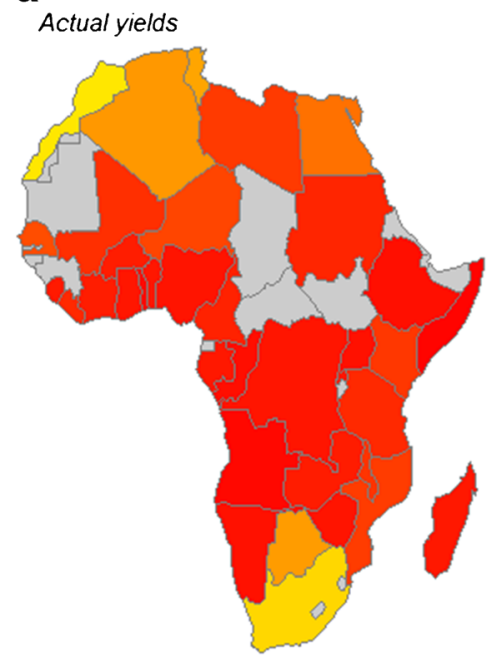

b

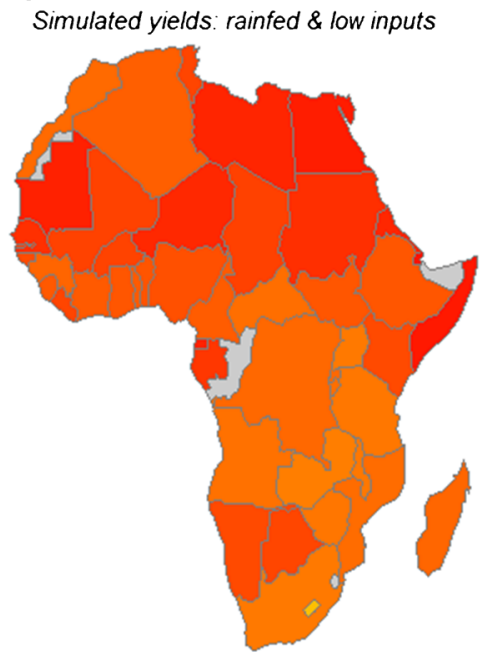

C Simulated potential yields

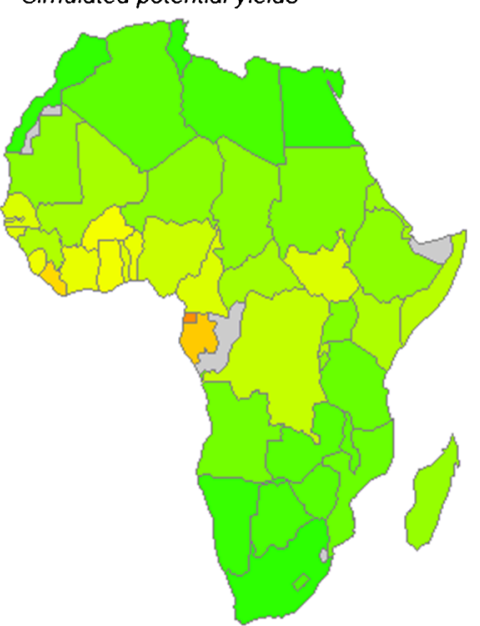

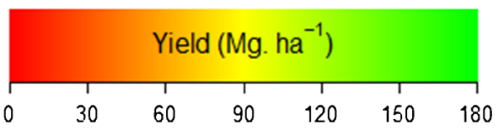

Fig. 2 Actual (a) and simulated national average yields of tomato cultivated in a rain-fed system with low inputs (b) and in an irrigated system with high inputs (c) for a baseline period 1961-1990. Actual yields were uploaded from FAOSTAT, and simulations of national average yields were uploaded from the GAEZ platform (www.gaez.fao. org) and converted from dry to fresh yield (in $\mathrm{tha}^{-1}$ ) considering a water

are the main soilborne vegetable pathogens in SSA (Fufa et al. 2009; Perez et al. 2017).

\subsubsection{Root-knot nematodes}

Over 90 species of Meloidogyne have been described but only four species are critical for vegetable production, M. incognita, M. javanica, M. arenaria, and $M$. hapla. M. incognita, M. javanica, and $M$. arenaria are common in tropical and sub-tropical regions, while $M$. hapla is only found at higher altitudes in the tropics. Recent studies also reported the importance of $M$. enterolobii (M. mayaguensis) in several regions in Africa (Onkendi et al. 2014).

It is estimated that root-knot nematodes account from 10 to $20 \%$ of vegetable crop losses worldwide (Sikora et al. 2018) but losses due to these pathogens is assumed to be underestimated especially in Africa (Onkendi et al. 2014). Most cultivated vegetables, along with the weeds commonly associated with them, are sensitive to or hosts of nematodes. The root systems of infested plants develop abnormally with the formation of typical galls that alter water and nutrient uptake and hence affect the water and mineral balance of the plant. Aboveground symptoms vary depending on the severity of the infestation from slight loss of vigor to death of the plant. The impacts of root-knot nematodes are worsened by the presence of fungal, i.e., Fusarium spp., or bacterial, i.e., $R$. solanacearum, soilborne pathogens that enter the plant content of $94.5 \%$ for fresh tomato. The high levels of inputs assume that high yielding varieties were used, crop nutrient and water requirements were fulfilled, and pest and diseases were fully controlled. In contrast, low levels of inputs assume that local varieties were used with minimum inputs

through the root lesions caused by the galls (Sikora et al. 2018).

Root-knot nematodes are considered as an increasing threat in Africa especially since commonly used nematicides, i.e., carbofuran and ethoprophos, are gradually disappearing (Onkendi et al. 2014; De Bon et al. 2014). Methods of control such as sanitation, soil management, organic amendments, fertilization, biological control, and heat-based methods only reduce nematode populations in the uppermost soil layers and for a limited period of time, so varietal resistance is considered as the most suitable method of control (Castagnone-Sereno and Djian-Caporalino 2011).

More than half the commercial solanaceous rootstocks of tomato listed in the USDA Horticultural Research Laboratory database are considered as resistant or highly resistant to rootknot nematodes (see http://www.vegetablegrafting.org/). Major genes have been identified in Solanaceae crops (i.e., $M i$ and $M e$ genes in tomato and pepper, respectively) that confer resistance against the main species of root-knot nematode (M. arenaria, M. incognita, and M. javanica). However, these resistances break down at temperatures of $30{ }^{\circ} \mathrm{C}$ and more, and the pathogenic variability of root-knot nematodes combined with the widespread use of the same resistant gene raise concerns about continued resistance (Castagnone-Sereno and Djian-Caporalino 2011; Jacquet et al. 2005).

In cucurbits, resistance to root-knot nematodes has been reported in some species including the African horned 
cucumber (Cucumis metuliferus) (Walters and Wehner 2002) and a wild species (Cucurbita pustulatus) (Liu et al. 2015) but incorporation in commercial varieties has not yet been successful (Castagnone-Sereno and Djian-Caporalino 2011). Several studies stressed the interest of $C$. metuliferus and C. pustulatus as rootstocks for cucurbits (cucumber, melon, and watermelon) to increase their resistance to root-knot nematodes (M. incognita) (Sigüenza et al. 2005; Liu et al. 2015). At the time of writing, less than a quarter of commercial cucurbit rootstock is said to be resistant to root-knot nematodes (see http://www.vegetablegrafting.org/). So, work is still required to propose farmers a range of effective cucurbit rootstocks to control nematodes.

\subsubsection{Bacterial wilt}

Bacterial wilt caused by $R$. solanacearum is a major disease affecting vegetables and is widespread in SSA (Fig. 3). Bacterial wilt can cause up to $100 \%$ crop losses and is consequently considered as one of the most serious diseases for solanaceous crops, including tomato, eggplant, sweet pepper, and African eggplant (Charrier et al. 1997; Fufa et al. 2009) and was also reported to affect Amaranthus (Sikirou et al. 2019) and cucurbit crops (Wicker et al. 2002) in tropical regions. The pathogen enters the plant through the roots and colonizes xylem tissue, thereby reducing the movement of water through the plant. The incidence of bacterial wilt varies with region, the crop, and the season. In Kenya, bacterial wilt was reported in $70 \%$ of potato fields (Muthoni et al. 2014), in $96 \%$ of hot pepper fields in Ethiopia (Assefa et al. 2015), and in between 60 and $80 \%$ of tomato plants in major tomatoproducing areas in the southwestern parts of Nigeria (Adebayo 2010). Increasing the resistance of Solanaceae varieties to bacterial wilt has been one of the main objectives of vegetable breeders for decades (Charrier et al. 1997; Fufa et al. 2009). Some commercial tomato varieties have been reported to have good resistance to bacterial wilt but this resistance is challenged by the high genetic diversity of the pathogen (Lebeau et al. 2011). Genetic markers enabled the classification of $R$. solanacearum strains in four phylotypes subdivided into sequevars. The phylotypes are linked to different geographical origins: I (Asian), II (American), III (African), and IV (Indonesian). Although the strains of the phylotype III have only been found in Africa so far, strains of phylotypes I and II are also widespread in SSA. The few studies conducted on the genetic diversity of $R$. solanacearum in SSA reported that the prevalence of each phylotype varies with the region. A higher proportion of phylotype I strains was reported in Ivory Coast (N'Guessan et al. 2012) than in Cameroon (Mahbou Somo Toukam et al. 2009). Grafting has long been used in Europe, North America, and Asia as a way to control bacterial wilt, but the resistance of the rootstock varies
Fig. 3 Current known distribution of major soilborne pathogens for vegetable crops, i.e., root-knot nematodes, e.g., Meloidogyne incognita, Meloidogyne hapla, and Meloidogyne Arenaria (a), Ralstonia solanacearum (b), Fusarium wilt, e.g., Fusarium oxysporum lycopersici (c) and Verticillium wilt, e.g., Verticillium dahliae and Verticillium albo-atrum (d). Data from EPPO (https://www.eppo. int/) and CABBI (https://www. cabi.org/) databases were used
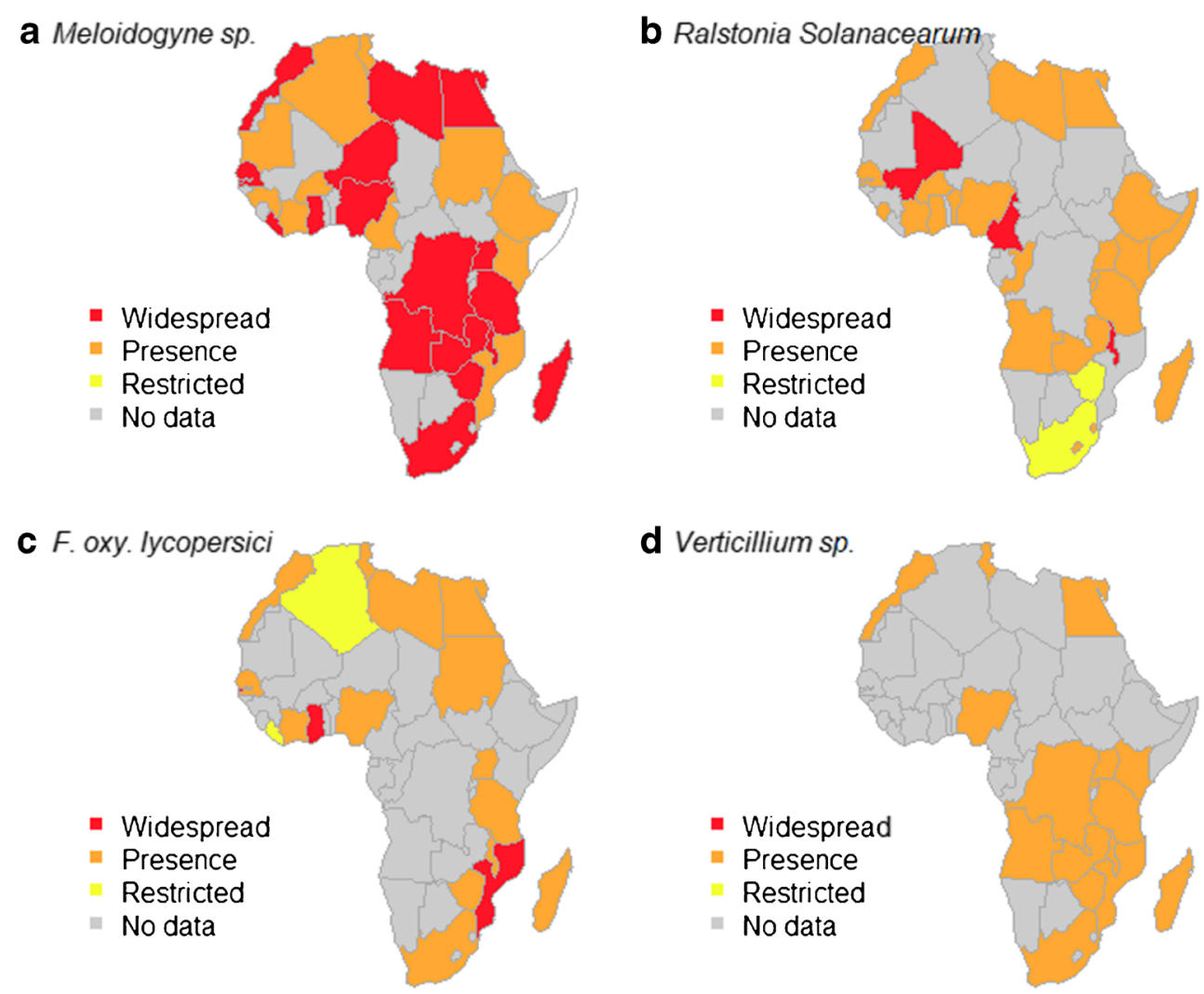
depending on local strains of the pathogen (Louws et al. 2010). An extensive study was conducted by Lebeau et al. (2011) who assessed the resistance of 30 accessions of tomato, eggplant, and sweet pepper known for their resistance to bacterial wilt to a core collection of 12 strains of the pathogen representative of its phylogenetic diversity. Their results highlighted marked variations in resistance between accessions but also notable differences in the sensitivity of the same plant to the different strains of the pathogen. Although higher resistance was found in eggplant accessions than in tomato and sweet pepper, the best accession, i.e., MM853 (INRA), was only fully resistant to four out of the 12 strains tested.

Few reports are available on the capacity of grafting to control bacterial wilt in SSA. A study in Nigeria stressed the interest of using a tomato landrace variety as a rootstock to increase the resistance to bacterial wilt but the impact on the yield was not reported (Ganiyu et al. 2016). A latter study conducted by the same authors reported the interest of grafting sensitive tomato varieties ('Beske' and 'UCB82-B') on a resistant tomato landrace rootstock ('Tomachiva') to improve the yield in infested soils by bacterial wilt (Ganiyu et al. 2018).

In Kenya and in Tanzania, some studies not only reported higher resistance of grafted plants to bacterial wilt but also pointed out that some rootstocks may have a detrimental impact on yield (Waiganjo et al. 2013; Mpinga 2013). Although the tomato rootstock 'Hawaii 7996' has been promoted as increasing the resistance of tomato to bacterial wilt in Asia (Black et al. 2003), it was found to be sensitive to some local strains in Ivory Coast (N'Guessan et al. 2012). Better results with the eggplant rootstocks 'EG203' also promoted in Asia were reported by these authors. Experiments conducted in Mayotte Island (Huat 2003) indicated that grafting tomatoes on 'EG203' and 'Hawaii 7796' delayed the appearance of wilting symptoms but this partial resistance was not sufficient to significantly improve the yields.

Different results were obtained in Tanzania on the use of 'Hawaii 7796' as a rootstock to improve the yield of tomatoes grown in soil infested by bacterial wilt. Experiments conducted in northern Tanzania indicated that grafting tomato cv. 'Tanya' on 'Hawaii 7796' significantly improved the yield, whereas further experiments in other sites did not establish significant differences between grafted and non-grafted plants (personal communication). Similarly, grafting tomatoes on 'EG203' rootstocks gave contrasting results in Mali which were thought to be related to different infection pressure levels and/or different strains.

Assessing the resistance of numerous rootstocks to a core collection of strains of $R$. solanacearum present in a given region under laboratory conditions, followed by multi-location trials conducted over several seasons, would help to identify resistant rootstocks that would improve yields of grafted solanaceous plants in soils infested by bacterial wilt.

\subsubsection{Fusarium wilt}

Fusarium is a large genus of imperfect fungi widely distributed around the world including several species that cause considerable damage to different crops including cereals and vegetables. Some Fusarium fungi are also a serious threat to human and livestock health because of the mycotoxins they produce. Fusarium mycotoxins are particularly preoccupying in SSA because of their high incidence in crops and food products (Chilaka et al. 2017). The traditional classification of Fusarium was based on morphology, leading to the inclusion of species with markedly different physiological traits. Host specificity, using the forma specialis system, was introduced to differentiate levels of virulence on host species or to group species among the Fusarium species (Suga and Hyakumachi 2004). In the Fusarium genus, oxysporum and solani species are the most serious pathogens for vegetables. Few reports on the impacts of these species on vegetable crops in SSA are available despite the fact their presence has been detected in different countries (Fig. 4). Wokoma (2008) reported F. oxysporum f. sp. lycopersici (FOL) to be a serious pathogen for tomato production in southern Nigeria. About 2 and $7 \%$ of wilted tomato plants collected in Benin were reported to be infested by $F$. solani and $F$. oxysporum, respectively (Sikirou et al. 2017).

Three physiological races, termed 1,2, and 3, are known on tomato. The incidence of Fusarium wilt of tomato was considerably reduced by the introduction of a single resistance gene, I, I2, and I3, in commercial cultivars (Inami et al. 2012). Grafting is nevertheless used to produce tomato varieties that do not exhibit resistance (Louws et al. 2010). Around $85 \%$ of tomato rootstocks were reported to be resistant to Fusarium wilt race 1 and race 2 but only a third is resistant to race 3 (see http://www.vegetablegrafting.org/). Another study reported the presence of race 3 of $F$. oxysporum $\mathrm{f}$. sp. lycopersici in the Eastern Cape area of South Africa (Jacobs et al. 2013). It worth noting that several open-pollinated varieties commonly cultivated in sub-Saharan Africa including Mongal, Thorgal, and Tengeru 97, are sensitive to Fusarium wilt and the control of this pathogen still relies on regular drenching with fungicides (Worku and Sahe 2018). F. oxysporum f. sp. melongenae was reported to affect eggplant and African eggplant (S. aethiopicum) production in Tanzania (Mwaniki et al. 2016). This study indicated that only 17 of the 93 accessions of African eggplant tested ( $S$. macrocarpon, $S$. aethiopicum, S. anguivi, and S. dasyphyllum) were resistant to F. oxysporum f. sp. melongenae (Mwaniki et al. 2016). The highest resistance was found in $S$. macrocarpon and $S$. aethiopicum accessions, underlining their interest as potential rootstocks. Fusarium spp. was identified in $17 \%$ of wilted hot pepper plants in Ethiopia; nevertheless, wilting symptoms cannot be only attributed to this fungus since $R$. solanacearum was also identified in all plant samples (Assefa et al. 2015). 
Fig. 4 Diversity of climatic conditions (a), rainfall deficit (b), organic matter content in the $0-30$ $\mathrm{cm}$ topsoil layer in sub-Saharan Africa (c), and average annual temperature (d). Climate conditions are described using the Köppen-Geiger climate classification for the period 1980 2016 with data adapted from Beck et al. (2018). The rainfall deficit was estimated using the aridity index as an indicator, i.e., annual rainfall over potential evapotranspiration, using data adapted from Antonio and Robert (2019). Average annual temperatures were computed from data provided by Fick and Hijmans (2017). Soil organic matter content was computed from the soil organic carbon content data provided by Hengl et al. (2015) using a conversion factor of 1.724
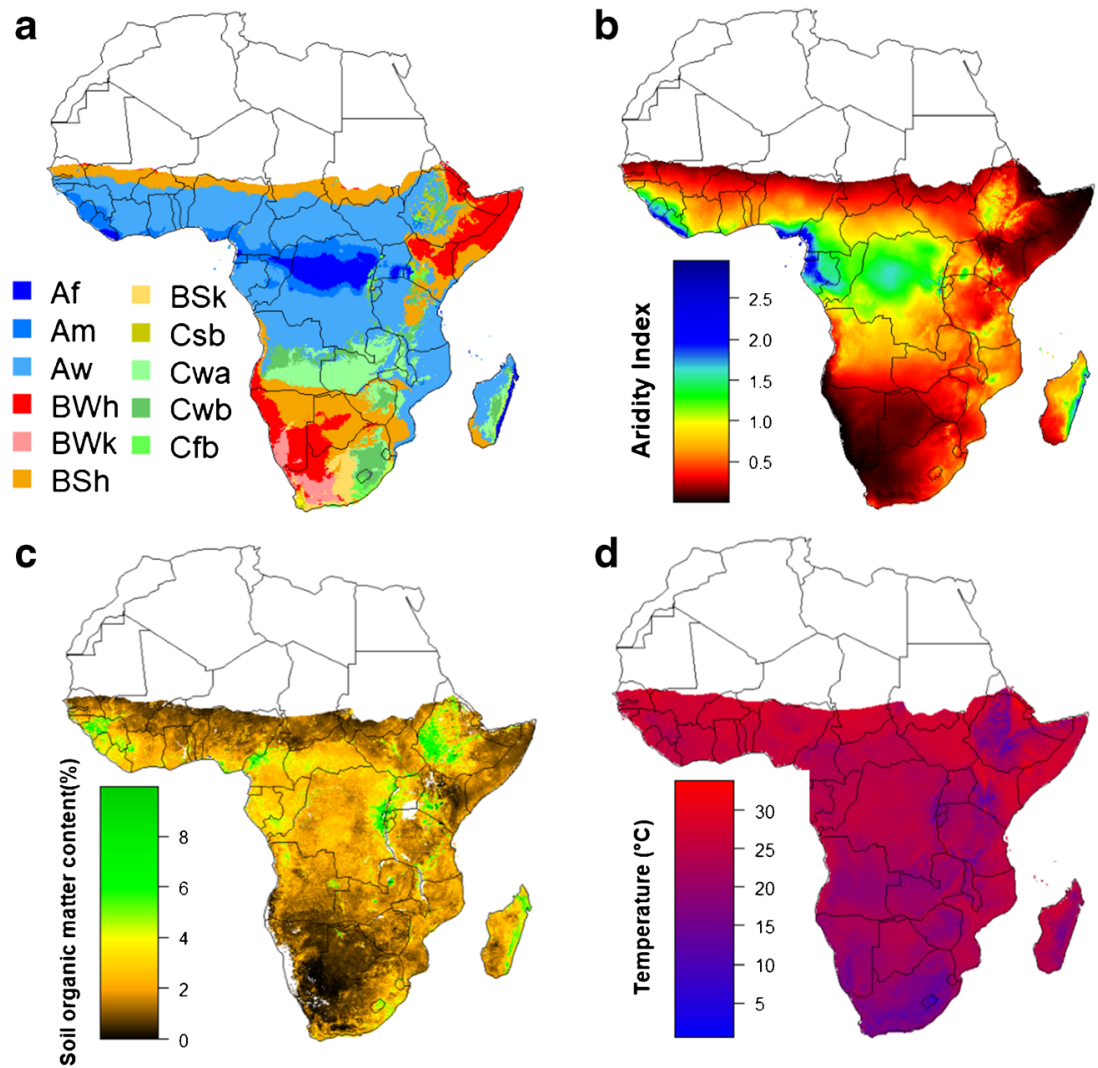

Several pepper rootstocks, i.e., 'Weishi' and 'Buyeding' were reported to increase the resistance of grafted plants to $F$. solani by increasing the development and change the secondary metabolism of the root system (Duan et al. 2017).

Cucurbit crops are also affected by Fusarium wilt caused by $F$. oxysporum f. sp. niveum (FON), F. oxysporum f. sp. melonis (FOM), and F. oxysporum f. sp. cucumerinum, which are responsible for significant crop losses in the USA, Europe, and Asia (Martyn 2014; Louws et al. 2010). Several reports referred to the impacts of these species on cucurbit production in North Africa and the advantage of grafting to control this pathogen (Boughalleb and El-Mahjoub 2010; Boughalleb and El Mahjoub 2006), but little information is available on Fusarium wilt of cucurbit crops in SSA. Further work would be so required to establish the pressure of Fusarium wilt in SSA and assess the interest of grafting.

\subsubsection{Verticillium wilt}

Verticillium dahliae and Verticillium albo-atrum are two fungi that can affect more than 400 herbaceous annual and perennial species and are considered as serious pathogens for solanaceous and cucurbit crops. $V$. dahlia is mainly found in tropical and subtropical regions whereas $V$. albo-atrum occurs predominately in temperate regions since growth stops at temperatures above $30{ }^{\circ} \mathrm{C}$ (Klosterman et al. 2009). Little information is available on the pressure of this fungus on vegetable crops in SSA. This may be partly explained by the fact that symptoms can be confused with those of Fusarium wilt. A study conducted in the south of Nigeria indicated that although Fusarium was the most prevalent in tomato crops, in certain fields, Verticillium was the causal agent of wilting of $60 \%$ of plants (Wokoma 2008). Similarly, a study conducted in Ethiopia indicated that around $12 \%$ of wilted hot pepper plants were infested by Verticillium spp. (Assefa et al. 2015). The impacts of Verticillium on tomato have been reduced by introducing resistance in commercial varieties (Gao et al. 2009), and most tomato rootstocks sold are resistant to Verticillium (see http://www.vegetablegrafting.org/). Verticillium wilt is considered as an emerging threat for melon production in Tunisia because of the lack of resistant varieties (Jabnoun-Khiareddine et al. 2007). Several studies reported the interest of grafting watermelon, melon, and cucumber to control Verticillium wilt (Paplomatas et al. 2000; Wimer et al. 2015).

\subsubsection{Other wilting diseases and pests}

Many other fungi and bacteria in addition to those mentioned in the previous sections are known to induce decay, damping off, or wilting in vegetable crops. Notably Phytophthora spp., Pythium spp., and Rhizoctonia solani are known to cause damping off on vegetables in the nursery and in the field. In tropical conditions, the impacts of these fungi are seasonal and 
limited to the coldest periods of the year. Since in the nursery, they can be managed by sterilizing the soil and in the field by drenching fungicides, grafting is not considered as a real option although several reports demonstrated the efficiency of different rootstocks (Louws et al. 2010). Clavibacter michiganensis, the causal agent of the bacterial canker, can cause considerable damage to Solanaceae crops. The disease is transmitted through seeds and during cultural operations, trellising and pruning plants. The percentage incidence of bacterial canker was reported to be $90 \%$ in tomato fields in the southern highlands of Tanzania (Black et al. 1999). The disease has also been reported in Madagascar, South Africa, Morocco, Kenya, and Egypt (EPPO 2019). Since this disease can penetrate the plant through the aboveground parts, stomata, and wounds, managing bacterial canker by grafting is limited in scope. A survey conducted in Benin reported that around $50 \%$ of wilted tomatoes plant collected were infested by Athelia rolfisii (= Sclerotinium rolfsii, the Southern blight) (Sikirou et al. 2017). The disease caused by A. rolfisii is particularly severe in the tropics and subtropics and can be managed using grafted plants (Rivard et al. 2010a; Louws et al. 2010).

Vine decline caused by Monosporascus cannonballus currently threatens melon production in Europe (García-Jiménez et al. 2000; Aleandri et al. 2016; Chilosi et al. 2008) and the USA (Bruton et al. 1995), but except in South Africa, it has yet not been reported in SSA (EPPO database).

Root parasitic weeds, including witchweed (Striga spp.) and broomrape (Orobanche spp. and Phelipanche ssp.) are considered as the most devastating agricultural weed pests worldwide. In Africa, several species of Striga cause considerable damages on cow pea (Vigna unguiculata) and on several cereals such as maize, rice, and sorghum (Samejima and Sugimoto 2018). Efforts have been made to screen resistant or tolerant tomato lines against broomrape which make considerable losses in the Mediterranean basin (Samejima and Sugimoto 2018) and a recent study even reported the interest of grating tomatoes on the 'Eldorado' rootstock (Draieab 2017). The occurrence of broomrapes in vegetable crops is sporadic in SSA and few reports on their impacts are available to date (Parker 2009).

Although underlying mechanisms are not well-known, several authors reported the interest of grafting to improve the plant resistance to virus, foliar pathogens, and arthropods (see Louws et al. 2010 for a review). The results on the improved resistance of grafted tomatoes to whiteflies (Bemisia tabaci) (Alvarez-Hernández et al. 2009) and transmitted virus (Mahmoud 2014) would be of interest in sub-Saharan regions where the apparition of resistance to pesticides makes it difficult to control this pest (Gnankine et al. 2013; Houndété et al. 2010). Nevertheless experiments conducted by Waiganjo et al. (2013) in Kenya did not confirmed the interest of tomato grafting for such application with the tested rootstock ('MT56').

\subsection{Abiotic stresses}

Around $8 \%$ of the African continent is hypothesized to be relatively free of natural constraints to agriculture (Jones et al. 2013). Production constraints vary between regions, particularly climate conditions and soil proprieties. SSA is characterized by a wide range of climate conditions (Fig. 4a). The most common climates are tropical $(52 \%)$, arid $(32 \%)$, and temperate (14\%) (Beck et al. 2018). In arid regions like the Sahel, the horn of Africa, and the western parts of South Africa, vegetable production is generally hindered by lack of access to water; vegetable production relies on rainfall because of the lack of and the high cost of irrigation water (Fig. 4b). In contrast, vegetable production in tropical regions is usually impacted by high rainfall, high temperatures, i.e., always higher than $18{ }^{\circ} \mathrm{C}$, and strong pathogen pressure. Maintaining the health status of the crop and the costs linked to the use of pesticides reduce vegetable production (Fufa et al. 2009). Temperate climate conditions prevail in the highlands in East Africa, the eastern part of South Africa, Zambia, southern Angola, the northern part of Botswana, and central Madagascar. In these regions, vegetable production can be hampered by low temperatures in the coldest season. Climate changes, notably changes in the amount and distribution of rainfall and heat waves, have a negative impact on agricultural production in SSA and modify the seasonality of vegetable production (Muthoni et al. 2018; Russo et al. 2016). The low fertility of the soil in SSA is one of the main obstacles to agricultural production (Smaling et al. 1997). Soil fertility varies with many soil traits including its capital reserve, leaching potential, organic carbon content, acidity, and cation exchange capacity (Tully et al. 2015). Soil organic matter (SOM) has been used as an indicator of the heterogeneity of soil fertility in SSA (Fig. 4c) because of its impacts on soil texture and on the water and nutrient retention capacity of soils (Andriesse and Giller 2015). Many uncertainties remain as to the desirable SOM content in soils depending on the methods used, i.e., expert panel or field experiments, the region concerned, and the soil texture (Loveland and Webb 2003). A recent study conducted under tropical conditions reported a critical SOM threshold varying from 3.3 to $3.8 \%$ (Musinguzi et al. 2016), in the same range as those in a review indicating that studies in temperate regions converge toward a threshold value of $3.4 \%$ (Loveland and Webb 2003). The average value of SOM in the topsoil $(0$ to $30 \mathrm{~cm})$ in SSA is about $2.1 \%$ (Fig. 4c). It is estimated that about $40 \%$ of the land in SSA has a low nutrient capital reserve, $25 \%$ presents aluminum toxicity, $18 \%$ has a high leaching potential, and $8 \%$ has a high phosphorus fixation rate (Tully et al. 2015). 
A lot of hope is invested in genetic improvement and the breeding of resilient varieties as an efficient and easy technique to increase farming success (Tester and Langridge 2010). However, plant tolerance to abiotic stress, such as high temperatures, drought, or salinity results from a combination of different fairly complex and multi-gene traits. For this reason, the lack of practical selection tools like genetic markers hinders the introduction of the complex traits into commercial cultivars and makes this approach slow and inefficient so far (Deikman et al. 2012; Tester and Langridge 2010). Furthermore, in developing countries, the development of breeding programs to support small farmers is also challenged by national research centers' lack of human and financial resources and by the limited economic incentives for private companies (Afari-Sefa et al. 2012). An appropriate method of adapting plants to offset abiotic stresses is by grafting commercial cultivars, local heirloom, and open pollinating varieties on selected elite rootstocks. The enhanced vigor and root growth of the rootstock can maintain or even increase yield independently of mechanisms to tolerate abiotic stress conditions. Numerous works have already highlighted the advantage of grafting vegetable species, including Solanaceae and Cucurbitaceae, to increase their tolerance to abiotic stresses (Rouphael et al. 2017a), particularly to drought (Kumar et al. 2017), heat (Schwarz et al. 2010), flooding, salinity (Colla et al. 2010a), and nutrient deficiency and soil imbalances (Savvas et al. 2010; Schwarz et al. 2010), and even toxicity of heavy metals (Edelstein and Ben-Hur 2018; Kumar et al. 2015). Here, we summarize the most important findings and discuss them under the special conditions exemplary for SSA but typical also for climatic similarly areas.

\subsubsection{High temperatures}

Supra-optimal temperatures have a complex series of effects on the vegetative and reproductive development of plants caused by direct damage to cells and by associated secondary stresses, such as osmotic and oxidative stresses (Wang et al. 2003). Among others, photosynthetic rate, respiration, assimilate partitioning, and water and ion balances of the plant are adversely affected by high temperatures. Reproductive development, i.e., pollen viability and fruit set, of Solanaceae and cucurbit crops is particularly sensitive to high temperature. An increase in average temperature from 25 to $28^{\circ} \mathrm{C}$ was reported to reduce the fruit set of tomato from $90 \%$ to less than $40 \%$, thereby reducing the yield more than fivefold (Harel et al. 2014). Similar results were reported for African eggplant: an increase in temperature from 30 to $40^{\circ} \mathrm{C}$ was reported to cause a more than threefold reduction in the number of fruit and to reduce the yield by $45 \%$ (Nkansah 2001). Annual temperatures higher than $25^{\circ} \mathrm{C}$ are recorded in $36 \%$ of SSA (Fig. 4d) (Fick and Hijmans 2017). Although the impact of grafting under sub-optimal temperatures has been widely studied and reviewed, knowledge on the impact of grafting at supraoptimal temperatures is poor (Schwarz et al. 2010; Rouphael et al. 2017a). Several trials indicated that grafted tomato, pepper, and cucumber plants were more tolerant of high temperatures than non-grafted plants, based on physiological indicators such as dry mass accumulation and phenolic content (Rivero et al. 2003; Abdelmageed and Gruda 2009). Grafting cucumber plants on luffa (Luffa cylindrica) rootstock increased the tolerance of plants to a temperature of $40{ }^{\circ} \mathrm{C}$ in the air and/or root zone. This seems to be a systemic response based on an ABA-dependent $\mathrm{H}_{2} \mathrm{O}_{2}$-driven mechanism ( $\mathrm{Li}$ et al. 2016). However, until now, only the commercial rootstock cultivar 'SQ60 F1' is available for cucumbers to improve heat tolerance (Rouphael et al. 2017b). Testing tomato rootstocks under hot and wet conditions in the tropics revealed 'Hawaii 7996' as a candidate rootstock. However, this was related to its resistance to bacterial and Fusarium wilt, which often occur under hot and wet conditions (Black et al. 2003). Eggplant was suggested as a rootstock to improve the heat tolerance of tomato, since eggplant is better adapted to hot dry climates. However, several trials produced contradictory results. In Egyptian experiments, the use of eggplant rootstocks had no advantage (Abdelmageed and Gruda 2009). On the other hand, using grafted eggplant was reported to prolong the growth period under high temperatures (Wang et al. 2006). This led to the recommendation to use the eggplant varieties 'VI046103' ('EG195') and 'VI045276' ('EG203') as rootstocks for tomato production under hot wet conditions (Keatinge et al. 2014). Only one seed company, Top Seeds Ibérica, recommends rootstocks with heat tolerance: the cvs 'Top Bental,' 'Top Gun,' and 'Top Pittam.' Mechanisms how rootstocks are able to increase tomato tolerance to heat have only been demonstrated using a transgenic rootstock in which the fatty acid desaturase 7 ( LeFAD7) gene was silenced (Nakamura et al. 2016). This reduced the amount of unsaturated fatty acids, which in turn, increased hightemperature tolerance. Palada and $\mathrm{Wu}$ (2008) compared the performances of grafted sweet pepper plants with non-grafted plants during the hot dry season in Taiwan. These authors tested 23 combinations of different Capsicum species, including C. chacoense, C. baccatum, C. frutescens, and C. annuum, but only three $C$. annuum produced a significantly higher yield than non-grafted plants (e.g., cvs 'Toom-1' and '985254 ').

These results demonstrate that grafting does not systematically lead to higher tolerance to high temperatures. If tolerance is available, plants call on several protection mechanisms against heat but the mechanisms may vary even in different genotypes of the same species. Most heat tolerance mechanisms have not been investigated in rootstock-scion combinations. Underlying traits can be demonstrated in different profiles of gene expression and metabolites (Paupière et al. 2014). If no tolerance is available, sufficient growth and yield 
might be obtained by selecting a vigorous rootstock with a larger root system. Since high temperature is a major constraint for vegetable production in hot dry regions, further research is urgently required to identify suitable combinations of scion and rootstocks to enhance adaptation of grafted plants to supra-optimal temperature.

\subsubsection{Drought and flood events}

Although it is reported that almost $20 \%$ of cropland in the world is currently irrigated, less than $5 \%$ of agricultural land in SSA benefits from irrigation (Burney et al. 2013). In SSA, rainfall ranges from 60 to more than $3100 \mathrm{~mm} /$ year (HarvestChoice 2015) resulting in major variations in rainfall deficits (Fig. 4b). Reduced water resources are often accompanied by increasing soil salinity and acidification (Jones et al. 2013). In addition to spatial variations, non-uniform distribution of rainfall over the year leads to alternating climate extremes, from drought to flooding.

Although tomato shoot biomass, mainly leaf area, of 'BHN 602 ' grafted on 'JjakKkung' was reduced compared with 'Cheong Gang' and self-grafted, this combination represented a strategy for water conservation because the scion was able to maintain mean midday $\mathrm{CO}_{2}$-saturated photosynthesis at lower water potentials (Nilsen et al. 2014). Comparing reciprocal grafts, the combination 'Josefina' (drought-sensitive, scion, cherry type) and 'Zarina' (drought-tolerant, rootstock) revealed a favorable relative water content in the leaf and enhanced growth response under moderate water stress of $50 \%$ crop evapotranspiration (Sánchez-Rodríguez et al. 2013). 'Josefina' grafted on 'Zarina' improved N, P, K uptake and uptake fluxes and enhanced the antioxidant enzyme activities while reducing membrane lipid peroxidation (SánchezRodríguez et al. 2014; Sánchez-Rodríguez et al. 2016). Under moderate water stress (80\% crop evapotranspiration), it might be sufficient to just use a vigorous rootstock (cv. 'Unifort') to improve water use efficiency (Ibrahim et al. 2014). Under water deficit, i.e., 50\% of optimal irrigation, grafting the commercial sweet pepper variety 'Hermino' on different commercial rootstocks increased the yield from 10 to $25 \%$ depending on the rootstock used, 'Creonte,' 'Terrano,' or 'Atlante' (López-Marín et al. 2017). Another study on sweet pepper reported more contrasted results since the tolerance of grafted plants to water stress varied with the rootstock used (Penella et al. 2014). Grafting 'Verset' on the rootstocks 'Atlante,' 'PI-152225,' or 'ECU-973' produced higher marketable yields than non-grafted plants while the five other rootstocks tested did not increase the yield. The same study also reported that grafting of sweet pepper did not increase the yield under well-watered conditions, whatever the rootstock used. Higher yields under water stress were obtained by grafting mini-water melon plants on a commercial interspecific rootstock, i.e., 'PS 1313' (C. maxima $\times$ C. moschata), enabled mainly by higher $\mathrm{N}, \mathrm{K}, \mathrm{Mg}$ uptake and higher net $\mathrm{CO}_{2}$ assimilation (Rouphael et al. 2008a). Increasing water use efficiency and consequently higher tolerance to drought was also confirmed in cucumber (cv. 'Jinyan No. 4') when it was grafted on luffa (L. cylindrica cv. 'Xiangfei No. 236') (Liu et al. 2016). All the cases mentioned above have in common that a specific rootstock-scion combination is important since screenings also revealed many combinations in which the rootstocks were unable to induce drought tolerance (Sakata et al. 2005).

Tomato grafting on eggplants (e.g., cv. 'Arka Neelkanth') was suggested to increase plant tolerance to flooding during the hot wet season in the tropics (Genova et al. 2013; Black et al. 2003; Bhatt et al. 2015). Similarly, the use of chili rootstocks was recommended to increase tolerance of grafted sweet pepper plants to flooding (Palada and Wu 2009). Several authors also reported the interest of grafting cucurbits to increase their tolerance to flooding, among which watermelon on bottle gourd (Lagenaria siceraria) (Yetisir et al. 2006) and bitter melon and bitter gourd on luffa (Liao and Lin 1996; Davis et al. 2008). Different modes of action were mentioned for these successful combinations, such as an increase in chlorophyll content, leaf $\mathrm{CO}_{2}$ exchange rate, stomatal conductance and transpiration rate, the development of aerenchyma and adventitious roots, and finally changes in glucose and sucrose concentrations.

\subsubsection{Nutrient deficiency or imbalances in the soil}

There is a consensus on the need to improve soil fertility in SSA and to prevent soil degradation (Jones et al. 2013), although the role of mineral fertilizers in soil fertility management is the subject of debate (Vanlauwe and Giller 2006). Several interlinked and unevenly spread phenomena threaten soil fertility in Africa such as water and wind erosion, the loss of nutrients and organic matter, and, to a lesser extent, salinization and soil contamination which are restricted to specific regions. It has been estimated that around $22 \%$ of productive land in Africa is impacted by soil degradation (Jones et al. 2013). Vegetable crops are sensitive to soil fertility since their mineral exports are high, from 150 to $250 \mathrm{~kg}$ and from 100 to $150 \mathrm{~kg}$ of nitrogen per hectare for solanaceous and cucurbit crops, respectively.

Because of their more vigorous root system that improves plant water and nutrient uptake, grafted plants are believed to be more tolerant to depleted soils. Several studies on tomatoes (Schwarz et al. 2013; Savvas et al. 2017), eggplant (Leonardi and Giuffrida 2006), and watermelon (Colla et al. 2010b; Colla et al. 2011; Huang et al. 2013) reported that grafting can increase plant nutrient uptake and nutrient use efficiency. Field experiments confirmed these results since yields of grafted tomato (Djidonou et al. 2015; Suchoff et al. 2019) and grafted melon (Colla et al. 2010b) were significantly 
higher than those of non-grafted plants even with a reduced supply of nitrogen. As mentioned above, the scion-rootstock combination is important for success in these cases too. Studies on melon indicated that grafting may reduce the absorption and translocation of minerals (Edelstein et al. 2016). Successful rootstocks under low-nitrate supply were cucurbit hybrid 'P360' for melon and 'Multifort' and 'Beaufort' for tomato. Recombinant inbred lines derived from a cross between two species closely related to cultivated tomato (S. lycopersicum var. cerasiforme $\times$ S. pimpinellifolium) are able to convert the scion into a nutrient-efficient phenotype with better $\mathrm{K}, \mathrm{S}$, and $\mathrm{Ca}$ assimilation and micronutrient $\mathrm{Zn}$, $\mathrm{Mn}, \mathrm{Fe}$, and $\mathrm{B}$ ) uptake and transport to the shoot (MartínezAndújar et al. 2016). As also mentioned above, salinity issues are restricted to some regions in SSA where rainfall and irrigation are not sufficient to leach salts. In these regions, grafting could increase plant tolerance to salinity. Increases of +25 to $+80 \%$ in yield were obtained using grafted tomato plants under saline conditions. Results varied with the degree of salinity stress and the scion-rootstock combination used (Estan et al. 2004; Martinez-Rodriguez et al. 2008). Similar results were obtained with sweet pepper since doubling the yield was obtained under saline conditions with certain rootstocks (Penella et al. 2017). Grafting has also been reported to be a valid strategy to improve salt tolerance of cucurbit crops since it increased the yield of watermelon (Colla et al. 2006a), cucumber (Huang et al. 2009), and melon (Colla et al. 2006b), by up to $80 \%, 98 \%$, and $44 \%$, respectively, under saline conditions. Lastly, the interest of grafting in reducing translocation of persistent organic pollutant, such as pesticides, and/or heavy metals from the soil to the plant has been investigated by several authors. One study revealed that specific rootstocks reduced the concentration of the pesticide dieldrin, in cucumber fruit when the plants were grown in contaminated soil with low carbon content (Otani and Seike 2007). Similar works on eggplant (Arao et al. 2008), cucumber (Rouphael et al. 2008b), and tomato (Kumar et al. 2015) reported that grafting may reduce translocation of heavy metals, i.e., cadmium and copper, from the soil to the plant. These results may be of interest in some regions in SSA where soils are contaminated by heavy metals due to mining or to the presence of industrial effluents (Jones et al. 2013).

\section{Adaption to economic and cultural contexts}

Although grafting is used in Northern Africa and in Asia to improve the plant resistance several abiotic and biotic stresses, this practice is not frequently used on vegetable crops in SSA despite they are impeded by similar agronomic challenges. In the following section, we analyze obstacles to the adoption of this technique for use with vegetable crops.

\subsection{Grafting is not a silver bullet}

Ranking of the major constraints to vegetable production varies with the location and the crop. Nevertheless, several pests are considered to be major constraints in most vegetable production regions in SSA, including whiteflies and associated virus, i.e., tomato yellow leaf curl virus (TYLCV), aphids, spider mites, and bollworms. The number of applications and the range of synthetic pesticides, e.g., organophosphates, carbamates, pyrethroids, and organochlorines, used to control pests on vegetable crops in SSA testify to the challenges faced by farmers (De Bon et al. 2014), to which must be added the emergence of resistance to pesticides in major insect pests of vegetables in SSA (Houndété et al. 2010). Crop losses due to aerial insect pests are expected to increase with the emergence of new species such as fruit flies (Bactrocera spp.), and the tomato leaf miner ( $T$. absoluta) which recently invaded SSA and causes significant damage to solanaceous and cucurbit crops (Mansour et al. 2018; Goergen et al. 2011). Although some studies reported that grafted plants may be more resistant to foliar pathogens and to whiteflies and related viruses, TYLCV (Mahmoud 2014; Louws et al. 2010), grafting alone cannot overcome aerial pests.

The marked spatial and seasonal variations in pressure from soilborne pathogens can reduce farmers' incentives to use grafted plants, as underlined by an impact assessment of the introduction of tomato grafting in Vietnam (Genova et al. 2013). Although tomato grafting was adopted by $100 \%$ of producers in the southern region (Lam Dong Province), the technique was used by less than a half the producers in the northern region (Red River Delta), because the pressure of bacterial wilt is irregular. Similar conclusions were reached in studies conducted in Washington State (USA) indicating that when the pressure of soilborne diseases is low, the advantages offered by the use of grafted plants do not suffice (Miles et al. 2014; Buller et al. 2013).

Several studies have provided evidence for the ability of grafting to increase plant resistance to abiotic stress, i.e., flooding, drought, low soil fertility, and high temperatures. However, the benefits of grafting to overcome such constraints need to be compared with the benefits of other agricultural practices including irrigation, raised bed, fertility management, or protected cultivation.

\subsection{Finding suitable combinations of scions and rootstocks}

In their extensive review of the performances of tomato grafted plants, Grieneisen et al. (2018) notably concluded that "the perception that rootstocks magically work to drive higher yields with any scion is an oversimplification."

Although the tomato rootstock 'Hawaii 7996' and the eggplant rootstocks 'EG203' varieties have been 
promoted as increasing the resistance of tomato to bacterial wilt in Asia (Black et al. 2003), their performances reported by the scarce published and non-published studies varied between sites and seasons in SSA (see section II. A. ii.).

These results are backed up by laboratory trials stressing the sensitivity of these rootstocks to several strains of $R$. solanacearum (Lebeau et al. 2011). When screening plants for grafting, the management of genotype $\times$ environment interactions is made more complex by interactions between the scion and the rootstock (Albacete et al. 2015). These complex interactions make it necessary to assess the individual performance of rootstock-scion combinations in multiple environments (Keatinge et al. 2014).

Today, more than 50 solanaceous and 27 cucurbit rootstocks are commercially available and their resistance to soilborne pathogens is relatively well described (http:// www.vegetablegrafting.org/). Most of these rootstocks are hybrids or interspecific hybrids: S. lycopersicum $\times$ $S$. habrochaites, and C. maxima $\times$ C. moschata (King et al. 2010). Vegetable production in SSA mainly relies on the use of open-pollinated varieties (OPVs), although hybrid varieties are being increasingly used (Perez et al. 2017). Old OPV varieties like 'Moneymaker,' 'Roma,' 'Tanya,' or 'Rio Grande' are still widely grown in SSA because of the lack of a reliable seed supply system and breeding efforts (Afari-Sefa et al. 2012). Because of the limited use of hybrid seeds so far, rootstock screening in SSA should therefore focus on suitable OPV varieties alongside commercial varieties adapted to local market requirements, i.e., post-harvest shelf life, color, and shape. Use of local landrace or wild species may be an interesting alternative to reduce the cost of grafting and insure the availability of seeds, as is the case in some Asian countries including India and Thailand where the $S$. torvum is used as a rootstock for grafting tomatoes and eggplants. The interest of using wild species like $S$. torvum as rootstocks to increase plant resistance to soilborne pathogens was stressed in several studies but their use is hampered by their heterogeneous germination and development rate, grafting incompatibility, and detrimental impact on plant vigor (Nordey et al. 2020). It is also worth noting that there is often a marked difference in stem diameter between the scion and the rootstock with heterografting which may weaken the grafting point. Despite production costs and challenges to grafting tomato on $S$. torvum, a few producers in Reunion Island have adopted this technique to grow indeterminate tomato varieties under shelter under high bacterial wilt pressure to respond to the increasing demand for organic products (Huat, personal communication). It can be assumed that breeding programs would help improve the grafting compatibility of wild species.

\subsection{Problems involved in obtaining grafted plants}

Challenges associated with grafting are well known and have been discussed by several authors (Lee 1994; Louws et al. 2010). Among the main limiting factors of vegetable grafting, cost, labor, technique, and the necessary equipment are the most often cited. To overcome these limitations, it has been suggested to promote vegetable grafting by nursery operators who would be responsible for supplying quality grafted plants to producers (Genova et al. 2013). Although this approach has been successful in Asia (Genova et al. 2013), its implementation in SSA is hindered by the fact that most vegetable producers in SSA are not used to producing or buying seedlings grown in seedling trays. Another challenge related to vegetable grafting is the need to synchronize scion and rootstock seedling development. Depending on the species, rootstock seedlings have to be sown from a few days to several weeks before the commercial scion seedlings to obtain the right stem diameter in both plants used for grafting (Nordey et al. 2020). The control of climate conditions in large commercial vegetable grafting nurseries facilitates the synchronization of the development of scion and rootstock seedlings (Kubota et al. 2017), but seasonal changes in temperature complicate the management of sowing schedules in low-cost nurseries. Grafting success also varies with climate conditions, i.e., temperature and air moisture. While graft-take ratios higher than $80 \%$ are commonly reported for vegetables (Vu et al. 2013), lower ratios are reported in hot climates (Huat 2003; Nordey et al. 2020).

A recent study showed that the grafting success rate of tomato declined from 90 to $20 \%$ with a temperature increase from 20 to $40{ }^{\circ} \mathrm{C}$ (Nordey et al. 2020). Similar results were reported by $\mathrm{Vu}$ et al. (2013) who indicated that increasing the temperature from 23 to $26^{\circ} \mathrm{C}$ reduced grafting success by 13 to $26 \%$ depending on the rootstock used. This study stated that 90\% air moisture should be maintained up to 3 days after grafting and then reduced to $70 \%$ during the healing and acclimatization phase to prevent the development of fungal diseases.

The use of low-cost grafting chamber such as a shaded low tunnel (Fig. 1h) or an underground chamber (Fig. 1i), was suggested to reduce temperatures and maintain a high humidity during the healing process (Nordey et al. 2020; Black et al. 2003). Combined with removal of leaves from the scion, reducing air moisture content also reduced the incidence of adventitious roots, which jeopardized the resistance of grafted plants to soilborne diseases (Meyer et al. 2017). The causes of appearance of adventitious roots are still unclear but the phenomenon varies with rootstock-scion combinations and is assumed to be caused by several factors including wounding, nutritional status, and climatic conditions (Geiss et al. 2018). There are also several points of divergence on the best practices for grafting vegetables, including the most suitable 
technique, equipment used, i.e., tube or clips, the position of the grafting point above or below cotyledons, the importance of staking, all of which require further investigation (Lee and Oda 2003; Black et al. 2003).

\subsection{The profitability of using grafted plants}

The profitability of grafting is linked to production costs (including the cost of grafted plants), the resulting increase in yield, and the market targeted. As discussed above, the increase in yield made possible by grafted plants varies with rootstock-scion combinations and production conditions, including the severity of soilborne pathogen pressure. A recent study indicated that among the 949 combinations of tomato grafted plants reviewed, only $35 \%$ produced higher yields than non-grafted plants (Grieneisen et al. 2018). On the other hand, the authors mentioned studies reporting that using grafted plants more than doubled yields. The cost of producing grafted plants varies with the species and techniques used. In the USA, production costs of grafted tomato plants were reported to be from 2.5 to 4.5 times higher than that of nongrafted seedlings (Rivard et al. 2010b; Barrett et al. 2012). These estimations were in the same range as those reported in a study conducted in Vietnam where grafted tomato plants were on average 2.7 times more expensive than non-grafted plants (Genova et al. 2013). An extensive analysis of production costs of grafted plants in the USA indicated that the switch from a low volume production system, i.e., manual grafting of one million of plants per year, to a high volume production system, i.e., automatic grafting of 100 million plants per year using robots, would reduce the cost of grafted plant from US\$0.15 to US\$0.12 for tomato and from US\$0.20 to US\$0.09 for watermelon (Lewis et al. 2014).

In Vietnam, the use of tomato grafted plants in the open field increased production costs by more than $75 \%$, but this was offset by the 2.5 times higher profits thanks to a $44 \%$ increase in yield (Genova et al. 2013). It is worth noting that the profitability and incentives to use grafted plants differ with the production system, i.e., open field or greenhouse cultivation, as well as with the target market, i.e., local, export, organic, or off-season. In Morocco, about $95 \%$ of tomatoes grown in greenhouses, mainly aimed at the export market, are grafted as an alternative to using methyl bromide (Besri 2007). Similar results were reported in Turkey where the suppression of methyl bromide encouraged farmers who use protected cultivation (low and high tunnels) to use grafted plants (Yetişir 2017). Although problems of soilborne pathogens are not limited to greenhouse production, intensive cultivation of high-value solanaceous and cucurbit crops for high profits favors the development of such pathogens. A recent survey in Kenya indicated that more than $80 \%$ and $60 \%$ of tomato producers using high tunnels reported problems with bacterial wilt and root-knot nematodes, respectively, even though the majority of farmers surveyed had started production less than 2 years previously (Ireri et al. 2018). It worth noting that the higher profits obtained per plant grown in a greenhouse offset the increased cost of a grafted plant better than the same plants grown in the open field. All the more since the indeterminate varieties commonly used in greenhouse cultivation are grown from 8 months to more than 1 year in contrast to determinate varieties that are cultivated in open fields for only 3 to 4 months.

Vegetable grafting can be also used to reach market niches. Grafting tomato on eggplant is used to increase the tolerance of plants to flooding, thereby enabling production in the hot wet season and hence when the market is favorable (Black et al. 2003). As previously mentioned, grafting is commonly used in North African countries as an alternative to chemical treatment for export crops (Besri 2007, 2008). In regions where there is increasing demand for organic products like in Europe and the USA, organic farmers are increasingly interested in using grafted plants to control soilborne diseases (Kubota et al. 2008; Barrett et al. 2012).

\section{Conclusions}

The success of vegetable grafting in different regions in the world to increase the resistance of plants to soilborne pathogens and to improve their tolerance to abiotic stresses sustain the hope that grafting could help to overcome similar agronomic challenges in SSA.

This review stresses that up to now efforts to promote vegetable grafting in SSA have been mainly focused on tomato to improve its resistance to bacterial wilt. Efforts to identify resistant rootstocks to soilborne diseases are hindered by the lack of knowledge on the distribution of soilborne pathogens in SSA and on suitable combinations of rootstocks and scions.

The transfer of experience on vegetable grafting is impeded by the fact that most of the commercial solanaceous and cucurbit rootstocks are hybrids or interspecific hybrids that are not intended to be used with the open-pollinated varieties commonly used in SSA. The use of open-pollinated solanaceous rootstocks that were developed and promoted to increase the resistance of tomatoes to bacterial wilt in Asia is challenged by the different strains of the pathogens in SSA. The use of resistant landraces and local wild species as rootstocks would reduce the price of grafted seedlings while guaranteeing the availability of seeds but their use is hampered by the slow and heterogeneous development of seedlings, the lower grafting success, and their impact on the plant vigor.

The identification of suitable rootstock-scion combinations is furthermore complicated by the fact that soilborne diseases are often combined with one or even several abiotic stresses. Both laboratory and field screening experiments are thus required to assess the performance of local grafted 
commercial cultivars under single and combined stresses. Improved insights on underlying tolerance mechanisms would support rootstock breeding, thereby broadening tolerance to abiotic stresses and the robustness of grafted plants.

Solanaceous and cucurbit crops are constrained by numerous factors, such as weeds, fungal diseases, and aerial insect pests that cannot be alleviated by simply using grafted plants. A combination of agricultural practices is therefore required to fully exploit the potential of grafted plants.

Efforts will be required to fine-tune techniques and equipment for vegetable grafting that is suitable for climatic conditions and investments of nursery operators in SSA. The capacity of nursery operators to provide a continuous supply of good-quality grafted plants should be built through technical and business trainings. Lastly, promoting the grafting of vegetables will require providing evidence to farmers, nursery operators, and extension officers for the profitability of using grafted plants in different production systems, i.e., open field and greenhouse, and for different markets, i.e., local, export, conventional, and organic.

Author contributions Thibault Nordey, Dietmar Schwarz, Lawrence Kenyon, Ravishankar Manickam, and Joel Huat conceived the present review. All authors wrote the manuscript with inputs from all authors.

\section{Compliance with ethical standards}

Conflict of interest The authors declare that they have no conflict of interest.

\section{References}

Abdelmageed A, Gruda N (2009) Influence of grafting on growth, development and some physiological parameters of tomatoes under controlled heat stress conditions. Eur J Hortic Sci 74(1):16-20

Adebayo OS (2010) Control of bacterial wilt disease of tomato: a review of research efforts in Nigeria. In: III International Symposium on Tomato Diseases. pp. 35-37

Afari-Sefa V, Tenkouano A, Ojiewo CO, Keatinge J, Hughes JA (2012) Vegetable breeding in Africa: constraints, complexity and contributions toward achieving food and nutritional security. Food Security 4(1):115-127

Affognon H, Mutungi C, Sanginga P, Borgemeister C (2015) Unpacking postharvest losses in sub-Saharan Africa: a meta-analysis. World Dev 66:49-68

Albacete A, Martinez-Andujar C, Martinez-Perez A, Thompson AJ, Dodd IC, Perez-Alfocea F (2015) Unravelling rootstockxscion interactions to improve food security. J Exp Bot 66(8):2211-2226. https://doi.org/10.1093/jxb/erv027

Aleandri M, Martignoni D, Reda R, Alfaro-Fernández A, Font M, Armengol J, Chilosi G (2016) Involvement of Olpidium bornovanus and $O$. virulentus in the occurrence of melon root rot and vine decline caused by Monosporascus cannonballus in Central Italy. J Plant Pathol 99(1):169-176

Alvarez-hernández JC, Cortez-Madrigal H, Garcia-Ruiz I, Ceja-Torres LF, Pérez-Domínguez JF (2009) Incidence of pests in grafts of tomato (Solanum lycopersicum) on wild relatives. Rev Colombiana Entomol 35(2):150-155
Andriesse W, Giller KE (2015) The state of soil fertility in sub-Saharan Africa. Agric Dev 24:32-36

Antonio T, Robert Z (2019) Global Aridity Index and Potential Evapotranspiration (ET0) Climate Database v2. https://doi.org/10. 6084/m9.figshare.7504448.v3

Arao T, Takeda H, Nishihara E (2008) Reduction of cadmium translocation from roots to shoots in eggplant (Solanum melongena) by grafting onto Solanum torvum rootstock. Soil Sci Plant Nutr 54(4): $555-559$

Assefa M, Dawit W, Lencho A, Hunduma T (2015) Assessment of wilt intensity and identification of causal fungal and bacterial pathogens on hot pepper (Capsicum annuum L.) in Bako Tibbe and Nonno districts of West Shewa Zone, Ethiopia. Int J Phytopathol 4(1):2128

Barrett CE, Zhao X, Hodges AW (2012) Cost benefit analysis of using grafted transplants for root-knot nematode management in organic heirloom tomato production. HortTechnology 22(2):252-257

Beck HE, Zimmermann NE, McVicar TR, Vergopolan N, Berg A, Wood EF (2018) Present and future Köppen-Geiger climate classification maps at 1-km resolution. Sci Data 5:180214. https://doi.org/10. 1038/sdata.2018.214

Besri M (2007) Economical aspects of grafting tomato in some Mediterranean countries. In: Proceedings of an Annual International Research Conference on Methyl Bromide Alternatives and Emissions. Citeseer, pp. 28-31

Besri M (2008) Cucurbits grafting as alternative to methyl bromide for cucurbits production in Morocco. In: Annual International Research Conference on Methyl Bromide Alternatives and Emissions Reductions, Orlando, Florida

Bhatt RM, Upreti KK, Divya M, Bhat S, Pavithra C, Sadashiva A (2015) Interspecific grafting to enhance physiological resilience to flooding stress in tomato (Solanum lycopersicum L.). Sci Hortic 182:8-17

Black R, Seal S, Abubakar Z, Nono-Womdim R, Swai I (1999) Wilt pathogens of Solanaceae in Tanzania: Clavibacter michiganensis subsp. michiganensis, Pseudomonas corrugata, and Ralstonia solanacearum. Plant Dis 83(11):1070-1070. https://doi.org/10. 1094/PDIS.1999.83.11.1070A

Black L, Wu D, Wang J, Kalb T, Abbass D, Chen J (2003) Grafting tomatoes for production in the hot-wet season. Asian Vegetable Res Dev Center AVRDC Public 3:551

Boughalleb N, El Mahjoub M (2006) Fusarium solani f. sp. cucurbitae and $F$. oxysporum $\mathrm{f}$. sp. niveum inoculum densities in Tunisian soils and their effect on watermelon seedlings. Phytoparasitica 34(2): $149-158$

Boughalleb N, El-Mahjoub M (2010) Frequency of Fusarium oxysporum f. sp. niveum and $F$. solani $\mathrm{f}$. sp. cucurbitae from watermelon seeds and their effect on disease incidence. Res J Parasitol 5(4):267-273

Bruton B, Davis R, Gordon T (1995) Occurrence of Acremonium sp. and Monosporascus cannonballus in the major cantaloupe and watermelon growing areas of California. Plant Dis 79(7):754

Buller S, Inglis D, Miles C (2013) Plant growth, fruit yield and quality, and tolerance to Verticillium wilt of grafted watermelon and tomato in field production in the Pacific Northwest. HortScience 48(8): 1003-1009

Burney JA, Naylor RL, Postel SL (2013) The case for distributed irrigation as a development priority in sub-Saharan Africa. Proc Natl Acad Sci 110(31):12513-12517

Castagnone-Sereno P, Djian-Caporalino C (2011) Lutte contre les nématodes à galles en cultures maraîchères: des recherches pour promouvoir la durabilité des résistances variétales. Innov Agronomiq 15:55-64

Charrier A, Jacquot M, Hamon S, Nicolas D (1997) L'amélioration des plantes tropicales. CIRAD, Montpellier

Chilaka C, De Boevre M, Atanda O, De Saeger S (2017) The status of Fusarium mycotoxins in sub-Saharan Africa: a review of emerging 
trends and post-harvest mitigation strategies towards food control. Toxins 9(1):19. https://doi.org/10.3390/toxins9010019

Chilosi G, Reda R, Aleandri M, Camele I, Altieri L, Montuschi C, Languasco L, Rossi V, Agosteo G, Macrì C (2008) Fungi associated with root rot and collapse of melon in Italy. EPPO Bull 38(1):147154

Colla G, Roupahel Y, Cardarelli M, Rea E (2006a) Effect of salinity on yield, fruit quality, leaf gas exchange, and mineral composition of grafted watermelon plants. HortScience 41(3):622-627

Colla G, Rouphael Y, Cardarelli M, Massa D, Salerno A, Rea E (2006b) Yield, fruit quality and mineral composition of grafted melon plants grown under saline conditions. J Hortic Sci Biotechnol 81(1):146152

Colla G, Rouphael Y, Leonardi C, Bie Z (2010a) Role of grafting in vegetable crops grown under saline conditions. Sci Hortic 127(2): $147-155$

Colla G, Suárez CMC, Cardarelli M, Rouphael Y (2010b) Improving nitrogen use efficiency in melon by grafting. HortScience 45(4): $559-565$

Colla G, Rouphael Y, Mirabelli C, Cardarelli M (2011) Nitrogen-use efficiency traits of mini-watermelon in response to grafting and nitrogen-fertilization doses. J Plant Nutr Soil Sci 174(6):933-941

Davis AR, Perkins-Veazie P, Sakata Y, López-Galarza S, Maroto JV, Lee S-G, Huh Y-C, Sun Z, Miguel A, King SR (2008) Cucurbit grafting. Crit Rev Plant Sci 27(1):50-74

De Bon H, Huat J, Parrot L, Sinzogan A, Martin T, Malézieux E, Vayssières J-F (2014) Pesticide risks from fruit and vegetable pest management by small farmers in sub-Saharan Africa. A review. Agron Sustain Dev 34(4):723-736

Deberdt P, Perrin B, Coranson-Beaudu R, Duyck P-F, Wicker E (2012) Effect of Allium fistulosum extract on Ralstonia solanacearum populations and tomato bacterial wilt. Plant Dis 96(5):687-692. https:// doi.org/10.1094/PDIS-07-11-0601

Deberdt P, Gozé E, Coranson-Beaudu R, Perrin B, Fernandes P, Lucas P, Ratnadass A (2015) Crotalaria spectabilis and Raphanus sativus as previous crops show promise for the control of bacterial wilt of tomato without reducing bacterial populations. J Phytopathol 163(5):377-385

Deikman J, Petracek M, Heard JE (2012) Drought tolerance through biotechnology: improving translation from the laboratory to farmers' fields. Curr Opin Biotechnol 23(2):243-250

Djidonou D, Lopiano K, Zhao X, Simonne EH, Erickson JE, Koch KE (2015) Estimating nitrogen nutritional crop requirements of grafted tomatoes under field conditions. Sci Hortic 182:18-26. https://doi. org/10.1016/j.scienta.2014.10.034

Doré T, Makowski D, Malézieux E, Munier-Jolain N, Tchamitchian M, Tittonell P (2011) Facing up to the paradigm of ecological intensification in agronomy: revisiting methods, concepts and knowledge. Eur J Agron 34(4):197-210. https://doi.org/10.1016/j.eja.2011.02. 006

Draieab R (2017) The role of grafting technique to improve tomato growth and production under infestation by the branched broomrape. ComprehenRes J Agric Sci 2(1):19-29

Duan X, Bi H, Li T, Wu G, Li Q, Ai X (2017) Root characteristics of grafted peppers and their resistance to Fusarium solani. Biol Plant 61(3):579-586

Dube T, Moyo P, Ncube M, Nyathi D (2016) The impact of climate change on agro-ecological based livelihoods in Africa: a review. J Sustain Dev 9(1):256-267

Edelstein M, Ben-Hur M (2018) Heavy metals and metalloids: sources, risks and strategies to reduce their accumulation in horticultural crops. Sci Hortic 234:431-444

Edelstein M, Cohen R, Elkabetz M, Pivonia S, Maduel A, Sadeh-Yarok T, Ben-Hur M (2016) The potential of enriched fertilization in overcoming nutritional deficiency in grafted melons. HortScience 51(4): $435-438$
EPPO Global Database (2019) https://gd.eppo.int. Accessed March 2019

Estan MT, Martinez-Rodriguez MM, Perez-Alfocea F, Flowers TJ, Bolarin MC (2004) Grafting raises the salt tolerance of tomato through limiting the transport of sodium and chloride to the shoot. J Exp Bot 56(412):703-712

Evenson RE, Gollin D (2003) Assessing the impact of the green revolution, 1960 to 2000. Science 300(5620):758-762. https://doi.org/10. $1126 /$ science. 1078710

FAO, IFAD, UNICEF, WFP, WHO (2018) The state of food security and nutrition in the world. FAO. doi:978-92-5-130,571-3

FAOSTAT (2017) Food and Agriculture Organization of the United Nations Statistical Database. http://www.fao.org/faostat/en/\#data/ QC. Accessed May 2019

Fick SE, Hijmans RJ (2017) WorldClim 2: new 1-km spatial resolution climate surfaces for global land areas. Int J Climatol 37(12):43024315

Fufa F, Hanson P, Dagnoko S, Dhaliwal M (2009) AVRDC-The World Vegetable Center Tomato Breeding in sub-Saharan Africa: lessons from the past, present work, and future prospects. In: J. Wesonga and R. Kahane Acta Hort. 911 I (ed) I All Africa Horticultural Congress 911. pp. 87-98.

Ganiyu S, Popoola A, Enikuomehin O, Bodunde J (2016) Tube grafting reduces incidence and severity of bacterial wilt in two tomato cultivars in Abeokuta, Nigeria. J Agric Sci Env 16(1):96-104

Ganiyu S, Popoola A, Enikuomehin O, Bodunde J (2018) Influence of grafting on growth and yield performance of two tomato cultivars grown in open field in Nigeria. J Plant Pathol 100(1):43-50

Gao Y, Zitter TA, Veilleux RE (2009) Verticillium wilt in solanaceous crops. Plant Breeding Rev 33:115-144

García-Jiménez J, Armengol J, Sales R, Jordá C, Bruton B (2000) Fungal pathogens associated with melon collapse in Spain. EPPO Bull 30(2):169-173

Geiss G, Gutierrez L, Bellini C (2018) Adventitious root formation: new insights and perspectives. Annual Plant Reviews online:127-156.

Genova C, Schreinemachers P, Afari-Sefa V (2013) An impact assessment of AVRDC's tomato grafting in Vietnam. AVRDC-The World Vegetable Center, Shanhua, Taiwan. AVRDC Publication No. 13-773. 52 p. Research in Action (8)

Gnankine O, Mouton L, Henri H, Terraz G, Houndeté T, Martin T, Vavre F, Fleury F (2013) Distribution of Bemisia tabaci (Homoptera: Aleyrodidae) biotypes and their associated symbiotic bacteria on host plants in West Africa. Insect Conserv Divers 6(3):411-421

Goergen G, Vayssières J-F, Gnanvossou D, Tindo M (2011) Bactrocera invadens (Diptera: Tephritidae), a new invasive fruit fly pest for the Afrotropical Region: host plant range and distribution in West and Central Africa. Environ Entomol 40(4):844-854. https://doi.org/10. 1603/en11017

Goldschmidt EE (2014) Plant grafting: new mechanisms, evolutionary implications. Front Plant Sci 5:727. https://doi.org/10.3389/fpls. 2014.00727

Grieneisen ML, Aegerter BJ, Stoddard CS, Zhang M (2018) Yield and fruit quality of grafted tomatoes, and their potential for soil fumigant use reduction. A meta-analysis. Agron Sustain Dev 38(3):29

Harel D, Fadida H, Slepoy A, Gantz S, Shilo K (2014) The effect of mean daily temperature and relative humidity on pollen, fruit set and yield of tomato grown in commercial protected cultivation. Agronomy 4(1):167-177

HarvestChoice (2015) Long-term annual rainfall (mm, 1960-2014). International Food Policy Research Institute, Washington, DC., and University of Minnesota, St. Paul

Hengl T, Heuvelink GB, Kempen B, Leenaars JG, Walsh MG, Shepherd KD, Sila A, MacMillan RA, de Jesus JM, Tamene L (2015) Mapping soil properties of Africa at $250 \mathrm{~m}$ resolution: random forests significantly improve current predictions. PLoS One 10(6): e0125814 
Houndété TA, Kétoh GK, Hema OS, Brévault T, Glitho IA, Martin T (2010) Insecticide resistance in field populations of Bemisia tabaci (Hemiptera: Aleyrodidae) in West Africa. Pest Manag Sci 66(11): 1181-1185

Huang Y, Tang R, Cao Q, Bie Z (2009) Improving the fruit yield and quality of cucumber by grafting onto the salt tolerant rootstock under $\mathrm{NaCl}$ stress. Sci Hortic 122(1):26-31. https://doi.org/10.1016/j. scienta.2009.04.004

Huang Y, Li J, Hua B, Liu Z, Fan M, Bie Z (2013) Grafting onto different rootstocks as a means to improve watermelon tolerance to low potassium stress. Sci Hortic 149:80-85

Huat J (2003) Etude de l'influence du greffage sur la production de tomate cultivée sous abri en pleine terre à Mayotte - Saison des pluies 2003/04. CIRAD, Montpellier

Ibrahim A, Wahb-Allah M, Abdel-Razzak H, Alsadon A (2014) Growth, yield, quality and water use efficiency of grafted tomato plants grown in greenhouse under different irrigation levels. Life Sci J 11(2):118-126

Inami K, Yoshioka-Akiyama C, Morita Y, Yamasaki M, Teraoka T, Arie $\mathrm{T}$ (2012) A genetic mechanism for emergence of races in Fusarium oxysporum f. sp. lycopersici: inactivation of avirulence gene AVR1 by transposon insertion. PLoS One 7(8):e44101. https://doi.org/10. 1371/journal.pone.0044101

Ireri DF, Murungi LK, Ngeno DC, Mbaka J (2018) Farmer knowledge of bacterial wilt and root-knot nematodes and practices to control the pathogens in high tunnel tomato production in the tropics. Int J Veg Sci: $1-13$

Jabnoun-Khiareddine H, Daami-Remadi M, Ayed F, Jebari H, El Mahjoub M (2007) Incidence of Verticillium wilt of melon in Tunisia. African J Plant Sci Biotechnol 1:10-15

Jacobs A, Govender R, van Heerden S (2013) Fusarium oxysporum f. sp. lycopersici race 3 causing tomato wilt in South Africa. Aust Plant Dis Notes 8(1):145-147

Jacquet M, Bongiovanni M, Martinez M, Verschave P, Wajnberg E, Castagnone-Sereno P (2005) Variation in resistance to the rootknot nematode Meloidogyne incognita in tomato genotypes bearing the Mi gene. Plant Pathol 54(2):93-99. https://doi.org/10.1111/j. 1365-3059.2005.01143.x

Jones A, Breuning-Madsen H, Brossard M, Dampha A, Deckers J, Dewitte O, Gallali T, Hallett S, Jones R, Kilasara M (2013) Soil atlas of Africa. Public Eur Union. https://doi.org/10.2788/52319

Keatinge J, Lin L-J, Ebert A, Chen W, Hughes JA, Luther G, Wang J-F, Ravishankar M (2014) Overcoming biotic and abiotic stresses in the Solanaceae through grafting: current status and future perspectives. Biol Agric Hortic 30(4):272-287

King SR, Davis AR, Zhang X, Crosby K (2010) Genetics, breeding and selection of rootstocks for Solanaceae and Cucurbitaceae. Sci Hortic 127(2):106-111

Klosterman SJ, Atallah ZK, Vallad GE, Subbarao KV (2009) Diversity, pathogenicity, and management of Verticillium species. Annu Rev Phytopathol 47:39-62. https://doi.org/10.1146/annurev-phyto080508-081748

Kubota C, McClure MA, Kokalis-Burelle N, Bausher MG, Rosskopf EN (2008) Vegetable grafting: history, use, and current technology status in North America. HortScience 43(6):1664-1669

Kubota C, Meng C, Son Y-J, Lewis M, Spalholz H, Tronstad R (2017) Horticultural, systems-engineering and economic evaluations of short-term plant storage techniques as a labor management tool for vegetable grafting nurseries. PLoS One 12(2):e0170614

Kumar P, Edelstein M, Cardarelli M, Ferri E, Colla G (2015) Grafting affects growth, yield, nutrient uptake, and partitioning under cadmium stress in tomato. HortScience 50(11):1654-1661

Kumar P, Rouphael Y, Cardarelli M, Colla G (2017) Vegetable grafting as a tool to improve drought resistance and water use efficiency. Front Plant Sci 8(1130):1130. https://doi.org/10.3389/fpls.2017. 01130
Kyriacou MC, Rouphael Y, Colla G, Zrenner R, Schwarz D (2017) Vegetable grafting: the implications of a growing agronomic imperative for vegetable fruit quality and nutritive value. Front Plant Sci 8(741):741. https://doi.org/10.3389/fpls.2017.00741

Lebeau A, Daunay M-C, Frary A, Palloix A, Wang J-F, Dintinger J, Chiroleu F, Wicker E, Prior P (2011) Bacterial wilt resistance in tomato, pepper, and eggplant: genetic resources respond to diverse strains in the Ralstonia solanacearum species complex. Phytopathology 101(1):154-165. https://doi.org/10.1094/PHYTO02-10-0048

Lee J-M (1994) Cultivation of grafted vegetables I. Current status, grafting methods, and benefits. HortScience 29(4):235-239

Lee JM, Oda M (2003) Grafting of herbaceous vegetable and ornamental crops. Hortic Rev 28:61-124

Lee J-M, Kubota C, Tsao SJ, Bie Z, Echevarria PH, Morra L, Oda M (2010) Current status of vegetable grafting: diffusion, grafting techniques, automation. Sci Hortic 127(2):93-105. https://doi.org/10. 1016/j.scienta.2010.08.003

Leonardi C, Giuffrida F (2006) Variation of plant growth and macronutrient uptake in grafted tomatoes and eggplants on three different rootstocks. Eur J Hortic Sci 71(3):97

Lewis M, Kubota C, Tronstad R, Son Y-J (2014) Scenario-based cost analysis for vegetable grafting nurseries of different technologies and sizes. HortScience 49(7):917-930

Li H, Ahammed GJ, Zhou G, Xia X, Zhou J, Shi K, Yu J, Zhou Y (2016) Unraveling main limiting sites of photosynthesis under below- and above-ground heat stress in cucumber and the alleviatory role of luffa rootstock. Front Plant Sci 7:746

Liao CT, Lin CH (1996) Photosynthetic responses of grafted bitter melon seedlings to flood stress. Environ Exp Bot 36(2):167-172

Liu B, Ren J, Zhang Y, An J, Chen M, Chen H, Xu C, Ren H (2015) A new grafted rootstock against root-knot nematode for cucumber, melon, and watermelon. Agron Sustain Dev 35(1):251-259

Liu S, Li H, Lv X, Ahammed GJ, Xia X, Zhou J, Shi K, Asami T, Yu J, Zhou Y (2016) Grafting cucumber onto luffa improves drought tolerance by increasing ABA biosynthesis and sensitivity. Sci Rep 6:20212. https://doi.org/10.1038/srep20212

López-Marín J, Gálvez A, del Amor FM, Albacete A, Fernández JA, Egea-Gilabert C, Pérez-Alfocea F (2017) Selecting vegetative/generative/dwarfing rootstocks for improving fruit yield and quality in water stressed sweet peppers. Sci Hortic 214:9-17. https://doi.org/ 10.1016/j.scienta.2016.11.012

Louws FJ, Rivard CL, Kubota C (2010) Grafting fruiting vegetables to manage soilborne pathogens, foliar pathogens, arthropods and weeds. Sci Hortic 127(2):127-146

Loveland P, Webb J (2003) Is there a critical level of organic matter in the agricultural soils of temperate regions: a review. Soil Tillage Res 70(1):1-18. https://doi.org/10.1016/s0167-1987(02)00139-3

Mahbou Somo Toukam G, Cellier G, Wicker E, Guilbaud C, Kahane R, Allen C, Prior P (2009) Broad diversity of Ralstonia solanacearum strains in Cameroon. Plant Dis 93(11):1123-1130. https://doi.org/ 10.1094/PDIS-93-11-1123

Mahmoud A (2014) Grafting as a tool to improve TYLCV-tolerance in tomato. J Hortic Sci Ornament Plants 6(3):109-115

Mansour R, Brévault T, Chailleux A, Cherif A, Grissa-Lebdi K, Haddi K, Mohamed SA, Nofemela RS, Oke A, Sylla S (2018) Occurrence, biology, natural enemies and management of Tuta absoluta in Africa. Entomol Gen 38(2):83-112

Martínez-Andújar C, Albacete A, Martínez-Pérez A, Pérez-Pérez JM, Asins MJ, Pérez-Alfocea F (2016) Root-to-shoot hormonal communication in contrasting rootstocks suggests an important role for the ethylene precursor aminocyclopropane-1-carboxylic acid in mediating plant growth under low-potassium nutrition in tomato. Front Plant Sci 7:1782

Martinez-Rodriguez MM, Estañ MT, Moyano E, Garcia-Abellan JO, Flores FB, Campos JF, Al-Azzawi MJ, Flowers TJ, Bolarín MC 
(2008) The effectiveness of grafting to improve salt tolerance in tomato when an 'excluder' genotype is used as scion. Environ Exp Bot 63(1):392-401. https://doi.org/10.1016/j.envexpbot.2007.12. 007

Martyn RD (2014) Fusarium wilt of watermelon: 120 years of research. Hortic Rev 42:349-442

Meyer LJ, Kennelly MM, Pliakoni ED, Rivard CL (2017) Leaf removal reduces scion adventitious root formation and plant growth of grafted tomato. Sci Hortic 214:147-157

Miles C, Wimer J, Inglis D (2014) Grafting eggplant and tomato for Verticillium wilt resistance. In: I International Symposium on Vegetable Grafting 1086. pp. 113-118.

Mpinga LE (2013) Tomato grafting for low-resource open-field tomato production in Tanzania. Master of Science thesis. Disseration for a master of science degree, University of Florida, Florida

Mudge K, Janick J, Scofield S, Goldschmidt EE (2009) A history of grafting. Hortic Rev 35:437-493. https://doi.org/10.1002/ 9780470593776.ch9

Musinguzi P, Ebanyat P, Tenywa JS, Basamba TA, Tenywa MM, Mubiru DN (2016) Critical soil organic carbon range for optimal crop response to mineral fertiliser nitrogen on a ferralsol. Exp Agric 52(4):635-653

Muthoni J, Kabira J, Shimelis H, Melis R (2014) Spread of bacterial wilt disease of potatoes in Kenya: who is to blame? Int J Horticult 4(3): $10-15$

Muthoni FK, Odongo VO, Ochieng J, Mugalavai EM, Mourice SK, Hoesche-Zeledon I, Mwila M, Bekunda M (2018) Long-term spatial-temporal trends and variability of rainfall over Eastern and Southern Africa. Theor Appl Climatol 1-14

Mwaniki PK, Abang MM, Wagara IN, Wolukau JN, Hans-Josef S (2016) Response of African eggplants to Fusarium spp. and identification of sources of resistance. Afr J Biotechnol 15(11):392-400

N'Guessan CA, Abo K, Fondio L, Chiroleu F, Lebeau A, Poussier S, Wicker E, Koné D (2012) So near and yet so far: the specific case of Ralstonia solanacearum populations from Cote d'Ivoire in Africa. Phytopathology 102(8):733-740

Nakamura S, Hondo K, Kawara T, Okazaki Y, Saito K, Kobayashi K, Yaeno T, Yamaoka N, Nishiguchi M (2016) Conferring hightemperature tolerance to nontransgenic tomato scions using graft transmission of RNA silencing of the fatty acid desaturase gene. Plant Biotechnol J 14(2):783-790

Nilsen ET, Freeman J, Grene R, Tokuhisa J (2014) A rootstock provides water conservation for a grafted commercial tomato (Solanum lycopersicum L.) line in response to mild-drought conditions: a focus on vegetative growth and photosynthetic parameters. PLoS One 9(12):e115380. https://doi.org/10.1371/journal.pone.0115380

Nkansah GO (2001) Some physiological features of the African eggplant, Solanum aethiopicum group 'Gilo'. Sci Hortic 90(1):181-186. https://doi.org/10.1016/S0304-4238(00)00254-5

Noble R, Coventry E (2010) Suppression of soil-borne plant diseases with composts: a review. Biocontrol Sci Tech 15(1):3-20. https:// doi.org/10.1080/09583150400015904

Nordey T, Shem E, Huat J (2020) Impacts of temperature and rootstocks on tomato grafting success rates. HortScience 1(aop):1-5

Onkendi EM, Kariuki GM, Marais M, Moleleki LN (2014) The threat of root-knot nematodes (Meloidogyne spp.) in Africa: a review. Plant Pathol 63(4):727-737

Otani T, Seike N (2007) Rootstock control of fruit dieldrin concentration in grafted cucumber (Cucumis sativus). J Pest Sci

Palada MC, Wu D-L (2009) Grafting sweet peppers for production in the hot-wet season. International Cooperator's Guide, AVRDC Publication Number: 09-722-e.

Palada MC, Wu D-L (2008) Evaluation of chili rootstocks for grafted sweet pepper production during the hot-wet and hot-dry seasons in taiwan. In, 2008. International Society for Horticultural Science
(ISHS), Leuven, Belgium, pp. 151-158. doi:https://doi.org/10. 17660/ActaHortic.2008.767.14

Paplomatas E, Elena K, Tsagkarakou A, Perdikaris A (2000) Control of Verticillium wilt of tomato and cucurbits through grafting of commercial varieties on resistant rootstocks. In: II Balkan Symposium on Vegetables and Potatoes 579. pp. 445-449

Parker C (2009) Observations on the current status of Orobanche and Striga problems worldwide. Pest Manag Sci: Former Pest Sci 65(5):453-459. https://doi.org/10.1002/ps. 1713

Paupière M, van Heusden A, Bovy A (2014) The metabolic basis of pollen thermo-tolerance: perspectives for breeding. Metabolites 4(4):889-920

Penella C, Nebauer SG, San Bautista A, López-Galarza S, Calatayud Á (2014) Rootstock alleviates PEG-induced water stress in grafted pepper seedlings: physiological responses. J Plant Physiol 171(10): 842-851. https://doi.org/10.1016/j.jplph.2014.01.013

Penella C, Nebauer SG, López-Galarza S, Quiñones A, San Bautista A, Calatayud Á (2017) Grafting pepper onto tolerant rootstocks: an environmental-friendly technique overcome water and salt stress. Sci Hortic 226:33-41. https://doi.org/10.1016/j.scienta.2017.08.020

Perez K, Froikin-Gordon JS, Abdourhamane IK, Levasseur V, Alfari AA, Mensah A, Bonsu O, Habsatou B, Assogba-Komlan F, Mbaye AA (2017) Connecting smallholder tomato producers to improved seed in West Africa. Agric Food Secur 6(1):42

Rivard CL, O'Connell S, Peet MM, Louws FJ (2010a) Grafting tomato with interspecific rootstock to manage diseases caused by Sclerotium rolfsii and southern root-knot nematode. Plant Dis 94(8):1015-1021. https://doi.org/10.1094/PDIS-94-8-1015

Rivard CL, Sydorovych O, O'Connell S, Peet MM, Louws FJ (2010b) An economic analysis of two grafted tomato transplant production systems in the United States. HortTechnology 20(4):794-803

Rivero RM, Ruiz JM, Romero L (2003) Can grafting in tomato plants strengthen resistance to thermal stress? J Sci Food Agric 83(13): 1315-1319

Rouphael Y, Cardarelli M, Colla G, Rea E (2008a) Yield, mineral composition, water relations, and water use efficiency of grafted miniwatermelon plants under deficit irrigation. HortScience 43(3):730 736. https://doi.org/10.21273/hortsci.43.3.730

Rouphael Y, Cardarelli M, Rea E, Colla G (2008b) Grafting of cucumber as a means to minimize copper toxicity. Environ Exp Bot 63(1-3): 49-58

Rouphael Y, Schwarz D, Krumbein A, Colla G (2010) Impact of grafting on product quality of fruit vegetables. Sci Hortic 127(2):172-179. https://doi.org/10.1016/j.scienta.2010.09.001

Rouphael Y, Kyriacou MC, Colla G (2017a) Vegetable grafting: a toolbox for securing yield stability under multiple stress conditions. Front Plant Sci 8:2255. https://doi.org/10.3389/fpls.2017.02255

Rouphael Y, Venema J, Edelstein M, Savvas D, Colla G, Ntatsi G, BenHur M, Kumar P, Schwarz D (2017b) Grafting as a tool for tolerance of abiotic stress. Vegetable grafting: principles and practices. $\mathrm{CAB}$ International, Wallingford, pp 171-215

Russo S, Marchese AF, Sillmann J, Immé G (2016) When will unusual heat waves become normal in a warming Africa? Environ Res Lett 11(5):054016

Sakata Y, Ohara T, Sugiyama M (2005) The history and present state of the grafting of cucurbitaceous vegetables in Japan. In: III International Symposium on Cucurbits 731. pp. 159-170

Samejima H, Sugimoto Y (2018) Recent research progress in combatting root parasitic weeds. Biotechnol Biotechnol Equip 32(2):221-240. https://doi.org/10.1080/13102818.2017.1420427

Sánchez-Rodríguez E, Romero L, Ruiz JM (2013) Role of grafting in resistance to water stress in tomato plants: ammonia production and assimilation. J Plant Growth Regul 32(4):831-842

Sánchez-Rodríguez E, Leyva R, Constán-Aguilar C, Romero L, Ruiz J (2014) How does grafting affect the ionome of cherry tomato plants under water stress? Soil Sci Plant Nutr 60(2):145-155 
Sánchez-Rodríguez E, Romero L, Ruiz J (2016) Accumulation of free polyamines enhances the antioxidant response in fruits of grafted tomato plants under water stress. J Plant Physiol 190:72-78

Savvas D, Colla G, Rouphael Y, Schwarz D (2010) Amelioration of heavy metal and nutrient stress in fruit vegetables by grafting. Sci Hortic 127(2):156-161

Savvas D, Öztekin GB, Tepecik M, Ropokis A, Tüzel Y, Ntatsi G, Schwarz D (2017) Impact of grafting and rootstock on nutrient-towater uptake ratios during the first month after planting of hydroponically grown tomato. J Hortic Sci Biotechnol 92(3):294-302

Schlenker W, Lobell DB (2010) Robust negative impacts of climate change on African agriculture. Environ Res Lett 5(1):014010

Schreinemachers P, Simmons EB, Wopereis MCS (2018) Tapping the economic and nutritional power of vegetables. Global Food Secur 16:36-45. https://doi.org/10.1016/j.gfs.2017.09.005

Schwarz D, Rouphael Y, Colla G, Venema JH (2010) Grafting as a tool to improve tolerance of vegetables to abiotic stresses: thermal stress, water stress and organic pollutants. Sci Hortic 127(2):162-171

Schwarz D, Öztekin GB, Tüzel Y, Brückner B, Krumbein A (2013) Rootstocks can enhance tomato growth and quality characteristics at low potassium supply. Sci Hortic 149:70-79. https://doi.org/10. 1016/j.scienta.2012.06.013

Sigüenza C, Schochow M, Turini T, Ploeg A (2005) Use of Cucumis metuliferus as a rootstock for melon to manage Meloidogyne incognita. J Nematol 37(3):276

Sikirou R, Beed F, Ezin V, Hoteigni J, Miller SA (2017) Distribution, pathological and biochemical characterization of Ralstonia solanacearum in Benin. Ann Agric Sci 62(1):83-88

Sikirou R, Dossoumou M-E, Zocli B, Afari-Sefa V, Honfoga J, Azoma K, Chen J-R, Paret ML, Bihon W (2019) First report of bacterial wilt of Amaranth (Amaranthus cruentus) caused by Ralstonia solanacearum in Benin. Plant Dis 103(3):578-578

Sikora RA, Coyne D, Hallmann J, Timper P (2018) Plant parasitic nematodes in subtropical and tropical agriculture. Cabi, Beijing, China

Smaling E, Nandwa SM, Janssen BH (1997) Soil fertility in Africa is at stake. Replenishing soil fertility in Africa (replenishingsoi):47-61

Suchoff DH, Gunter CC, Schultheis JR, Hassell RL, Louws FJ (2019) The effect of grafting on nitrogen use in determinate field-grown tomatoes. J Hortic Sci Biotechnol 94(1):102-109

Suga H, Hyakumachi M (2004) Genomics of phytopathogenic Fusarium. In: Arora DK, Khachatourians GG (eds) Applied mycology and biotechnology, vol 4. Elsevier, pp. 161-189. doi:https://doi.org/10. 1016/S1874-5334(04)80009-1.

Tester M, Langridge P (2010) Breeding technologies to increase crop production in a changing world. Science 327(5967):818-822. https://doi.org/10.1126/science. 1183700

Tully K, Sullivan C, Weil R, Sanchez P (2015) The state of soil degradation in sub-Saharan Africa: baselines, trajectories, and solutions. Sustainability 7(6):6523-6552

Vanlauwe B, Giller KE (2006) Popular myths around soil fertility management in sub-Saharan Africa. Agric Ecosyst Environ 116(1-2): $34-46$
Vu N-T, Zhang C-H, Xu Z-H, Kim Y-S, Kang H-M, Kim I-S (2013) Enhanced graft-take ratio and quality of grafted tomato seedlings by controlling temperature and humidity conditions. 시 원예· 식 22(2):146-153

Waiganjo M, Omaiyo D, Gathambiri C, Kuria S, Njeru C, Kleinhenz M, Kovach J, Miller S, Erbaugh M (2013) Effects of grafting and high tunnel tomato production on pest incidence, yield and fruit quality in smallholder farms in Central Kenya. East African Agric Forestry J 79(2):107-111

Walters SA, Wehner TC (2002) Incompatibility in diploid and tetraploid crosses of Cucumis sativus and Cucumis metuliferus. Euphytica 128(3):371-374

Wang W, Vinocur B, Altman A (2003) Plant responses to drought, salinity and extreme temperatures: towards genetic engineering for stress tolerance. Planta 218(1):1-14. https://doi.org/10.1007/s00425-003$1105-5$

Wang S, Cheng J, Zhao J, Yang R (2006) Effect of rootstocks on the tolerance to high temperature of eggplants under solar greenhouse during summer season. In: XXVII International Horticultural Congress-IHC2006: International Symposium on Advances in Environmental Control, Automation 761. pp. 357-360

Wezel A, Casagrande M, Celette F, Vian J-F, Ferrer A, Peigné J (2013) Agroecological practices for sustainable agriculture. A review. Agron Sustain Dev 34(1):1-20. https://doi.org/10.1007/s13593013-0180-7

Wicker E, Grassart L, Mian D, Coranson Beaudu R, Dufeal D, Guilbaud C, Prior P (2002) Cucumis melo, Cucumis sativus, Cucurbita moschata, and Anthurium spp., new hosts of Ralstonia solanacearum in Martinique (French West Indies). Bact Wilt Newslett 17:20-21

Wimer J, Inglis D, Miles C (2015) Field and greenhouse evaluations of cucurbit rootstocks to improve Verticillium resistance for grafted watermelon. HortScience 50(11):1625-1630

Wokoma E (2008) Preliminary report on diseases of tomato in Choba, Rivers State. J Appl Sci Environ Manag 12(3):178-221

Worku M, Sahe S (2018) Review on disease management practice of tomato wilt caused Fusarium oxysporum in case of Ethiopia. J Plant Pathol Microbiol 9(11):2. https://doi.org/10.4172/2157-7471. 1000460

Yetișir H (2017) History and current status of grafted vegetables in Turkey. Chronic Horticult 57:13-18

Yetisir H, Caliskan ME, Soylu S, Sakar M (2006) Some physiological and growth responses of watermelon [Citrullus lanatus (Thunb.) Matsum. and Nakai] grafted onto Lagenaria siceraria to flooding. Environ Exp Bot 58(1-3):1-8

Publisher's note Springer Nature remains neutral with regard to jurisdictional claims in published maps and institutional affiliations. 